\title{
Geochemistry, geochronology and mineralisation potential of the granites in the Central Iberian Zone: The Jalama batholith
}

\author{
Casilda Ruiz ${ }^{\mathrm{a}}$, Concepción Fernández-Leyva ${ }^{\mathrm{b}}$, Juan Locutura ${ }^{\mathrm{b}}$ \\ ${ }^{a}$ The Madrid School of Mines, Polytechnic University of Madrid, Rios Rosas 21, Madrid 28003, Spain \\ ${ }^{\mathrm{b}}$ Geological Survey of Spain, Madrid, Spain
}

\begin{abstract}
The Jalama batholith (Spain and Portugal) is one of the numerous granites of the Central Iberian Zone with Sn- and $\mathrm{W}$-associated mineralisation. On the basis of petrographical and geochemical characterisation three types of granite have been distinguished: inhomogeneous granitoids, porphyrytic granites and leucogranites, all of these being peraluminous and subalkaline. All the granites correspond to S-type granites. The field data, the petrography and lack of geochemical affinity relationships of the leucogranites with the remaining granites indicate that their geneses correspond to an independent magma batch and superimposed fractional crystallisation process. The granitic units show subparallel REE patterns. There is a decrease in total REE and an increase in the negative Eu anomaly from the inhomogeneous granitoids to leucogranites. Some leucogranites show relatively low contents of Sn and W almost certainly due to segregation in the magma of a melt rich in water carrying $\mathrm{Sn}-\mathrm{W}$. These elements are concentrated in the water phase, which eventually gives rise to $\mathrm{Sn}-\mathrm{W}$-associated mineralisation.

The ages obtained by means of a whole-rock $\mathrm{Rb}-\mathrm{Sr}$ isochron for the granites mainly indicate an early intrusion of the inhomogeneous granitoids $(319 \pm 10 \mathrm{Ma})$, followed in time by porphyrytic granites $(279 \pm 9 \mathrm{Ma})$, which can be associated to the late-post-kinematic granites within the third Variscan deformation phase $\left(\mathrm{D}_{3}\right)$.

Apart from the average $\mathrm{Sn}$ content, the variations of trace elements, principally $\mathrm{Sr}, \mathrm{Ba}, \mathrm{Rb}$, Th and $\mathrm{P}$, establish that the porphyritic granites and the inhomogeneous granitoids will be barren granites while the leucogranites and the subfacies at the margin of the porphyritic granites correspond to granites with mineralisation potential. It is precisely in these granites of the Jálama batholith that the $\mathrm{Sn}-\mathrm{W}$ mineralisation is located, for which the criteria utilised has been demonstrated to be effective.
\end{abstract}

\section{Introduction}

In the Iberian Massif of the European Hercynian Belt, there is a well-exposed cross section of continental crust, affected by Variscan collision of continental masses during late Devonian to Carboniferous times that generated a large volume of granites (Ribeiro et al., 1983; Matte, 1986).

In the Central Iberian Zone (CIZ) of the Iberian Massif, large volumes of granitoids were emplaced during the post-collisional stage of the Hercynian 
orogeny (syn-to post- $\mathrm{D}_{3}$, the last Variscan deformation phase) (Ferreira et al., 1987), varying its composition from alumino-potassic to calc-alkaline and subalkaline types.

The understanding of the geochemistry of the granites in the CIZ of the Iberian Massif has interested many authors (Corretgé, 1983; Bea et al., 1987; Villaseca and Herreros, 2000) but not in terms of its relationship to mineralisation potential, and addressing this latter has a special interest, in view of the fact that the majority of the $\mathrm{Sn}-\mathrm{W}$ deposits related to the Hercynian granites are located in the CIZ. The Hercynian granites of the Iberian Peninsula with which these types of deposits are related have been characterised in agreement with their relationships with the different tectonic phases, geochemically, and from the petrographic point of view - among other authors - by Villaseca (1985) and Fúster and Villaseca (1988). Only Saavedra (1982) studied, in a general manner, the geochemical characteristics of some mid-western Spanish granites, applied to the discrimination of barren granites from those exhibiting a potential for hosting Sn mineralisation.

In the Jalama batholith, situated in the southern part of the CIZ of the Iberian Massif, the studies have been centred basically on the mapping of facies and their field relationships (Martín Herrero et al., 1984; García de Figuerola et al., 1985a, b) and in the petrographical and geochemical characterisation of the batholith (Saavedra and Pellitero, 1973, 1975; Saavedra et al., 1977; Ramírez and Grundvig, 2000).

The objectives set out for the Jalama batholith are the following:

- To establish the different types of granites in the batholith by means of petrographical and geochemical characterisation.

- To understand the ages of the more important granite bodies, by means of the $\mathrm{Rb} / \mathrm{Sr}$ whole rock method.

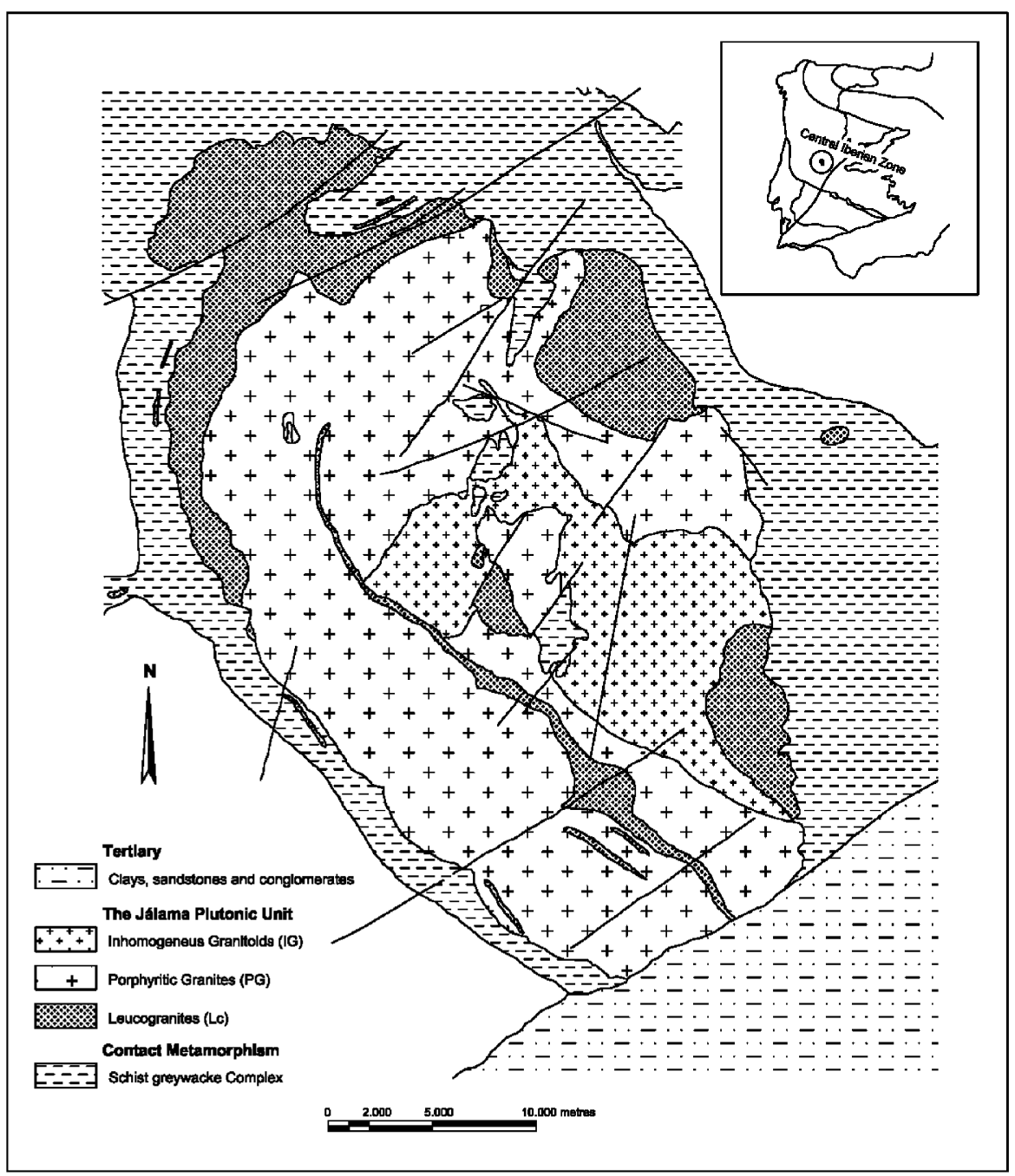

Fig. 1. Schematic geological map of the Jálama granite batholith. 
- To determine the mineralisation potential for the different types of granites, by means of the variations in the content of selected indicator elements.

From the results of the previous sections and their coherence, we try to develop criteria to distinguish granitoids with mineralisation potential from barren ones in the Jálama batholith and, in a general manner, in the CIZ.

\section{Geological setting}

The Jálama granitic batholith has an area of $200 \mathrm{~km}^{2}$, an oval shape and is mainly located in the NW of the province of Cáceres and, to a lesser extent, to the SW of Salamanca and in Portugal (Fig. 1). It is one of the numerous granites with $\mathrm{Sn}$ and $\mathrm{W}$ associated mineralisation in the Iberian Hercynian basement.

This batholith forms an enclave in the southern part of the CIZ of the Iberian Massif, within the domain of vertical folds (Díez Balda et al., 1990) and emplaced in the material of the Upper Precambrian in the slategreywacke facies (Schist-Greywacke Complex). This complex, affected by a low-grade regional metamorphism, is a formation in which two units separated by an unconformity can be distinguished stratigraphically (Robles and Àlvarez-Nava, 1988). The lower series of the Schist-Greywacke Complex outcrops to the $\mathrm{W}$ and $E$ of the batholith, which comprises a thick sequence of sandstones and shales with occasional intercalations of conglomerates and amphibolites. The upper series of the complex outcrops only to the $\mathrm{E}$ of the batholith and this is mainly composed of lutites, although in other areas shales, sandstones and intercalated bands of conglomerates have been observed.

The composition of the Jalama batholith varies from monzogranitic-granite to leucogranitic. Associated with the latter is mineralisation of Sn, mainly in the form of cassiterite, and/or W principally in veins of quartz. Of much lesser importance is the disseminated Sn mineralisation.

The contact metamorphic aureole, which surrounds the batholith in the western zone, consists of a band between 0.5 and $1.5 \mathrm{~km}$ wide, being greater than $5 \mathrm{~km}$ in the eastern zone. The Jálama batholith is a late- and post-kinematic intrusion (Serrano Pinto et al., 1987), with respect to the main phases of the Hercynian deformation of the Devonian Upper-Middle Carboniferous (Martínez Catalán, 1990; Díez Balda et al., 1995).

\section{Granitoides of the Jálama batholith}

The different granitic units have been established by means of recognition in the field, petrographic study and the classification of samples according to the scheme of La Roche (1992).
Table 1. Modal composition of Jálama batholith granites (\% vol)

\begin{tabular}{llllll}
\hline Facies & Quartz & K-feldspar & Plagioclase & Muscovite & Biotite \\
\hline IG & 25.3 & 31.2 & 35.3 & 3.9 & 4.2 \\
PG & 26.5 & 32.4 & 33.5 & 5.5 & 2.1 \\
Lc & 34.4 & 48.2 & 7.5 & 8.8 & 0.1 \\
\hline
\end{tabular}

The average modal composition of the most representative samples of the granitic units, were determined using a point counter (Table 1).

\section{Two-mica inhomogeneous granitoids (IG)}

The two-mica inhomogeneous granitoids are dispersed in a wide band parallel to the elongation of the pluton, from the SE margin to the two-thirds point in a NW direction (Fig. 1). It corresponds to a two-mica granite of hypidiomorphic texture (locally poikilitic) mainly composed of quartz, plagioclase (oligoclasealbite), K-feldspar, biotite and muscovite. The larger crystals of quartz $(1-3 \mathrm{~mm})$ are anhedral and equidimensional, and the remainder form rounded inclusions in the K-feldspar. The phenocrysts of plagioclase can reach $5 \mathrm{~mm}$ in length, show polysynthetic twinning and abundant inclusions of quartz and biotite, while the crystals of the mesostasis do not reach $1 \mathrm{~mm}$ in size, are tabular and poor in inclusions. The $\mathrm{K}$-feldspar is subidiomorphic, tabular and about $3 \mathrm{~mm}$ in length. Muscovite and biotite appear in isolated crystals or in aggregates. The muscovite exhibits greater deformation than the biotite and has inclusions of sillimanite. The accessory minerals are sillimanite, apatite, zircon, ore minerals and tourmaline.

In this facies, two subfacies can be distinguished in terms of the abundance of micaceous enclaves of likely restitic origin: restite-rich granites (fine grain size, heterogeneously porphyritic and abundant biotite) and restite-poor granites (larger grain size, more homogeneously porphyritic and greater percentage of quartz and K-feldspar).

This facies corresponds to a granite-monzogranite according to La Roche (1992) (Fig. 2).

\section{Two-mica porphyritic granite-monzogranite (PG)}

These granites occupy approximately $50 \%$ or the total area of the batholith (Fig. 1). The inhomogeneous granitoids are cross-cut by the two-mica porphyritic granite-monzogranite. These monzogranites have a variable porphyrytic character (sometimes equigranular) composed of quartz, K-feldspar, plagioclase (oligoclasealbite), muscovite and biotite. The quartz appears in anhedral equidimensional crystals, with serrated bound- 


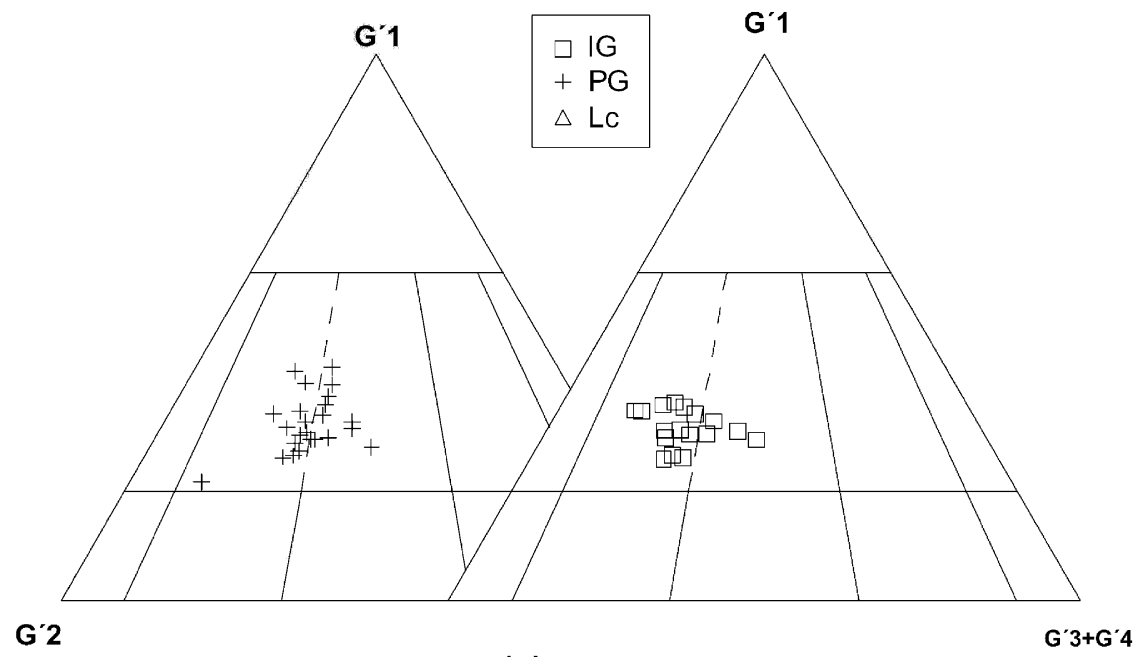

(a)

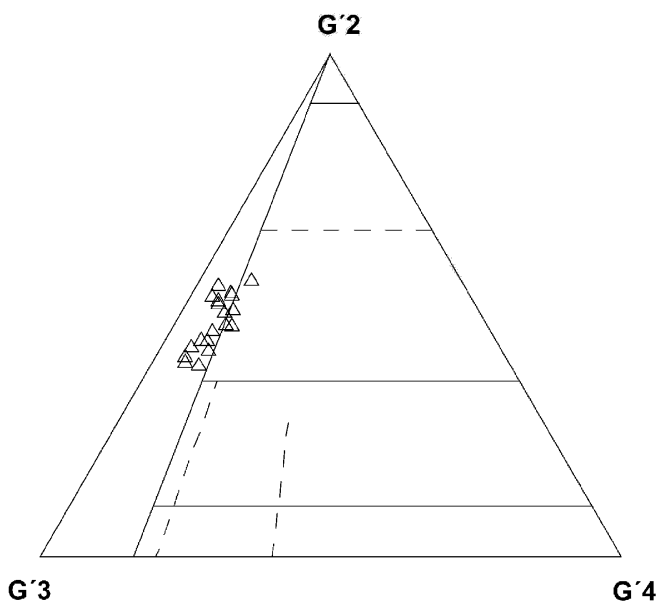

(b)

Fig. 2. Classification of samples according to the scheme of La Roche (1992). (a) Inhomogeneous granitoids and porphyritic granites. (b) Leucogranites. Note: $\mathrm{G}^{\prime} 1=\mathrm{Si}+(\mathrm{Fe}+\mathrm{Mg}-\mathrm{Ti}) / 5-2 \mathrm{Ca}-3 \mathrm{Na}-3 \mathrm{~K} ; \mathrm{G}^{\prime} 2=-3 \mathrm{Al}-6(\mathrm{Fe}+\mathrm{Mg}-\mathrm{Ti}) / 5+6 \mathrm{Ca}+3 \mathrm{Na}+9 \mathrm{~K}$; $\mathrm{G}^{\prime} 3=\mathrm{Al} / 2+(\mathrm{Fe}+\mathrm{Mg}-\mathrm{Ti})-6 \mathrm{Ca}+9 \mathrm{Na} / 2-3 \mathrm{~K} / 2 ; \mathrm{G}^{\prime} 4=10 \mathrm{Ca}$, where $\mathrm{Si}, \mathrm{Al}, \mathrm{Ca} \ldots$ are abundances of the major cations, calculated from the analytical data (in $\mathrm{wt} \%$ ).

aries up to $1 \mathrm{~cm}$ of diameter, and in inclusions within the plagioclase and the K-feldspar. The latter forms subidiomorphic and poikilitic phenocrysts of large size with inclusions of all the other phases. The phenocrysts of plagioclase reach up to $7 \mathrm{~mm}$ in length, generally with albite. The muscovite is more abundant and of greater size than the biotite. Accessory minerals are apatite, zircon, tourmaline, ore minerals and topaz.

This facies corresponds to a granite-monzogranite according to La Roche (1992) (Fig. 2).

\section{Leucogranites (Lc)}

The distribution of the leucogranites in the Jálama batholith, as well as to the $\mathrm{E}$ of the same in the metamorphic host rock, can be seen in Fig. 1. The northern leucogranites display transitional contacts with the porphyrytic granites, contrary to the other granites with which they have net contacts.

All these display equigranular texture, grain size medium to fine, and are composed of quartz, Kfeldspar, plagioclase (albite) and muscovite. Accessory minerals are apatite, tourmaline, biotite, ore minerals, zircon and topaz. The tourmaline can, in certain zones, be relatively abundant.

This facies corresponds to alkali feldspar granite according to La Roche (1992) (Fig. 2).

\section{Analytical methods}

\section{Analytical procedures in geochemistry}

A total of 66 samples were analysed. The sample quantity was $10 \mathrm{~kg}$ for the coarse-grained facies and between 3 and $4 \mathrm{~kg}$ 
for the fine-grained facies. Each sample was subjected to a process of crushing by consecutive stages to reach $63 \mu \mathrm{m}$. A total of 44 elements (major and trace) were determined, of which, 42 were analysed in the accredited laboratories of Activation Laboratories Ltd. in Ancaster (Ontario, Canada). $\mathrm{F}$ and $\mathrm{Li}$ were analysed in the laboratories of the Geological Survey of Spain (IGME).

The samples were run for major oxides and selected trace elements ( $\mathrm{Ba}, \mathrm{Sr}, \mathrm{Y}, \mathrm{Sc}, \mathrm{Zr}, \mathrm{Be}$ y V) on a combination simultaneous/sequential Thermo Jarrel-Ash ENVIRO II ICP or a Spectro Cirros ICP, with precisions better than $\pm 2 \%$. Samples were mixed with a flux of lithium metaborate and lithium tetraborate and fused in an induction furnace. The molten melt was immediately poured into a solution of $5 \%$ nitric acid containing an internal standard, and mixed continuously until completely dissolved. The rest of the trace elements (except $\mathrm{Li}$ and $\mathrm{F}$ ) were analysed on a Perkin Elmer SCIEX ELAN 6000 ICP-MS, with precisions better than $\pm 4 \%$.

The determination of $\mathrm{Li}$ was carried out by means of acid attack $\left(\mathrm{HF}+\mathrm{HNO}_{3}+\mathrm{HClO}_{4}\right)$ to dryness and dissolution in $10 \% \mathrm{HCl}$ and the measurement completed by Atomic Absorption Spectrophotometry on a Varian Model SpectrAA $220 \mathrm{FS}$ instrument, with a precision of about $\pm 3 \%$. The determination of $\mathrm{F}$ was carried out by means of extraction of the same by pyrohydrolisis with tungsten oxide (VI) and the method of measurement was by UV/visible spectrophotometry of the discoloration of alizarin-zirconium in a Corning unit model 258 , with a precision of about $\pm 8 \%$.

\section{Analytical procedures in geochronology}

The isotopic signatures ${ }^{87} \mathrm{Rb} /{ }^{86} \mathrm{Sr}$ and ${ }^{87} \mathrm{Sr} /{ }^{86} \mathrm{Sr}$ were determined for a total of 14 samples of fresh rock representative of the most important granitic units of the Jálama batholith: seven samples of the inhomogeneous granitoids and seven samples of the porphyritic granites.

The samples, of approximately $10 \mathrm{~kg}$ each, were put through a jaw crusher and a ball mill, both of stainless steel, then pulverised in an agate mortar. From the homogenised and pulverised sample, $0.5 \mathrm{~g}$ was taken which was attacked with a mixture of $\mathrm{HF}$ and $\mathrm{HClO}_{4}(1: 5)$, separating the $\mathrm{Rb}$ and the $\mathrm{Sr}$ by cation exchange chromatography with resin AG $50 \mathrm{~W}-\mathrm{X} 8$.

The contents of $\mathrm{Rb}$ and $\mathrm{Sr}$ and the ratio $\mathrm{Rb} / \mathrm{Sr}$ in wholerock, were measured by X-ray spectrometry.

The isotopic composition of the $\mathrm{Sr}$ was determined by mass spectrometry on a Varian Mat TH5 in the laboratories of the IGME. Re double filaments were used. The instrumental fractionation was corrected by normalising the value to the ratio ${ }^{86} \mathrm{Sr} /{ }^{88} \mathrm{Sr}=0.1194$. In the whole-rock procedure, the isotopic composition of the $\mathrm{Sr}$ was measured directly on samples without a spike.

The errors in these determinations have been estimated at maximum $1.5 \%$ for the ratio ${ }^{87} \mathrm{Rb} /{ }^{86} \mathrm{Sr}$ and $0.2 \%$ for the ratio ${ }^{87} \mathrm{Sr} /{ }^{86} \mathrm{Sr}$. In these global limits of the relative error are included systematic errors and random errors of the analytic procedure. The blank contribution of the Sr to the measurements was always less than $0.5 \%$.

The isochrons have been adjusted using a linear leastsquares regression programme weighted with the precision of the measurements according to the method of York-Williamson. The decay constant used was $\lambda^{87} \mathrm{Rb}=1.42 \times 10^{-11} /$ year, value recommended by the I.U.G.S. (Steiger and Järger, 1977). As a criterion of confidence for the points on the isochron, the MSWD value was used. The errors shown for the ages and the initial ratios of ${ }^{87} \mathrm{Sr} /{ }^{86} \mathrm{Sr}$ correspond to $1 \sigma$ errors.

\section{Geochemistry}

\section{Major and trace elements}

In the Jálama batholith, chemical analyses have been carried out on 66 samples (only most representative are shown in Table 2) and all of these are peraluminous as can be seen in the diagram $\mathrm{A}-\mathrm{B}, \quad(\mathrm{A}=\mathrm{Al}-(\mathrm{K}+$ $\mathrm{Na}+2 \mathrm{Ca})$ and $(\mathrm{B}=\mathrm{Fe}+\mathrm{Mg}+\mathrm{Ti})$ of Debon and Le Fort (1988) (Fig. 3) in which we can distinguish moreover the samples of leucogranites, that is, with less than $7 \%$ of dark minerals ( $\mathrm{B}$ is less than $38.8 \mathrm{~g}$ atoms $\times 10^{3}$ ). Likewise, the granites are subalkaline, as can be seen in the diagram alkalis versus silica (Fig. 4).

The rocks exhibit high concentrations of $\mathrm{SiO}_{2}$ $(65.21-76.11 \%), \mathrm{P}_{2} \mathrm{O}_{5}(0.26-0.63 \%)$ and alkalis. The ratio $\mathrm{K} / \mathrm{Na}$ varies between $1.12 \%$ and $3.22 \%$ being, in general, lower in the leucogranites than in the porphyritic granites and the inhomogeneous granitoids. The contents of $\mathrm{Al}_{2} \mathrm{O}_{3}, \mathrm{TiO}_{2}, \mathrm{Fe}_{2} \mathrm{O}_{3}$, and $\mathrm{MgO}$ range from moderate to low (Table 2; Fig. 5). These trends in the Harker diagrams are probably the expressions of twocomponent mixing or unmixing. This is the case for the biotite which has been carried by the melt as solid crystals. Ba exhibits concentrations of moderate to low and decrease with the content of silica. On the contrary, $\mathrm{Li}, \mathrm{F}, \mathrm{Rb}, \mathrm{Sn}, \mathrm{W}$ and Ta tend to increase with the superimposed differentiation (Table 2; Fig. 6).

\section{Rare earth elements}

The chondrite-normalised REE of the three granitic units are subparallel, with a negative Eu anomaly, a greater content of LREE with respect to HREE, which presents a normalised pattern close to the horizontal (Fig. 7). The values of the negative Eu anomaly $\left(\mathrm{Eu} / \mathrm{Eu}^{*}\right)$ in the different granites vary between 0.15 and 0.56. The leucogranites present a negative Eu anomaly with values which vary between 0.15 and 0.37 , greater, as such, than the porphyritic granites and inhomogeneous granitoids which lie between 0.24 and 0.56 (Table 2). The increase in the content of LREE $\left(\mathrm{La}_{n} / \mathrm{Sm}_{n}\right)$ for all the granitic units varies from 2.12 to 3.48 .

$\sum$ REE decreases from the inhomogeneous granitoids (average value in REE: 731.1), passing through the porphyritic granites (average value in REE: 484.7 ) to the leucogranites (average value in REE: 203.75) (Table 2). 
Table 2. Representative chemical analyses for the Jalama granites: whole rock major element (in wt \%), trace element and rare elements (in ppm)

\begin{tabular}{|c|c|c|c|c|c|c|c|c|c|c|c|c|c|}
\hline $\begin{array}{l}\text { Sample } \\
\text { Facies }\end{array}$ & $\begin{array}{l}17 \\
\mathrm{IG}\end{array}$ & $\begin{array}{l}44 \\
\mathrm{I} G\end{array}$ & $\begin{array}{l}61 \\
\mathrm{IG}\end{array}$ & $\begin{array}{l}65 \\
\mathrm{IG}\end{array}$ & $\begin{array}{l}11-A \\
P G\end{array}$ & $\begin{array}{l}26 \\
P G\end{array}$ & $\begin{array}{l}38 \\
P G\end{array}$ & $\begin{array}{l}42 \\
P G\end{array}$ & $\begin{array}{l}43 \\
P G\end{array}$ & $\begin{array}{l}50 \\
\mathrm{Lc}\end{array}$ & $\begin{array}{l}12 \\
\mathrm{Lc}\end{array}$ & $\begin{array}{l}31 \\
\mathrm{Lc}\end{array}$ & $\begin{array}{l}34 \\
\mathrm{Lc}\end{array}$ \\
\hline $\mathrm{SiO}_{2}$ & 69.74 & 69.29 & 69.99 & 69.96 & 71.98 & 70.56 & 72.3 & 71.41 & 72.05 & 74.23 & 73.18 & 73.75 & 73.42 \\
\hline $\mathrm{Al}_{2} \mathrm{O}_{3}$ & 15.35 & 16.05 & 15.27 & 15.55 & 14.76 & 15.38 & 14.46 & 15.9 & 14.71 & 14.64 & 14.61 & 14.6 & 15.09 \\
\hline $\mathrm{Fe}_{2} \mathrm{O}_{3}$ & 2.34 & 3.00 & 2.44 & 2.42 & 1.74 & 2.66 & 2.47 & 1.09 & 2.59 & 1.06 & 1.52 & 1.35 & 1.49 \\
\hline $\mathrm{MnO}$ & 0.020 & 0.031 & 0.036 & 0.022 & 0.025 & 0.024 & 0.033 & 0.011 & 0.037 & 0.026 & 0.042 & 0.025 & 0.032 \\
\hline $\mathrm{MgO}$ & 0.63 & 0.81 & 0.67 & 0.58 & 0.30 & 0.61 & 0.46 & 0.28 & 0.48 & 0.16 & 0.22 & 0.25 & 0.35 \\
\hline $\mathrm{CaO}$ & 0.33 & 0.50 & 0.70 & 0.31 & 0.41 & 0.48 & 0.86 & 0.28 & 0.74 & 0.35 & 0.45 & 0.23 & 0.36 \\
\hline $\mathrm{Na}_{2} \mathrm{O}$ & 2.08 & 2.20 & 2.61 & 1.98 & 3.12 & 2.32 & 3.05 & 2.62 & 3.05 & 3.44 & 3.11 & 2.45 & 2.07 \\
\hline $\mathrm{K}_{2} \mathrm{O}$ & 5.56 & 5.24 & 5.33 & 5.69 & 4.81 & 5.35 & 4.78 & 6.83 & 4.97 & 4.10 & 4.54 & 4.20 & 4.65 \\
\hline $\mathrm{TiO}_{2}$ & 0.359 & 0.493 & 0.395 & 0.438 & 0.189 & 0.447 & 0.344 & 0.165 & 0.378 & 0.081 & 0.170 & 0.164 & 0.202 \\
\hline $\mathrm{P}_{2} \mathrm{O}_{5}$ & 0.46 & 0.28 & 0.36 & 0.46 & 0.49 & 0.36 & 0.38 & 0.33 & 0.39 & 0.42 & 0.45 & 0.41 & 0.38 \\
\hline LOI & 2.91 & 2.12 & 1.43 & 2.64 & 1.54 & 1.88 & 0.78 & 1.36 & 1.08 & 1.24 & 1.38 & 2.35 & 1.98 \\
\hline Total & 99.77 & 100.00 & 99.24 & 100.05 & 99.37 & 100.08 & 99.91 & 100.28 & 100.47 & 99.75 & 99.67 & 99.78 & 100.03 \\
\hline $\mathrm{Sc}$ & 4 & 6 & 5 & 4 & 3 & 4 & 5 & 2 & 6 & 4 & 3 & 3 & 3 \\
\hline $\mathrm{Be}$ & 7 & 8 & 9 & 6 & 8 & 6 & 5 & 4 & 5 & 6 & 7 & 6 & 7 \\
\hline V & 18 & 32 & 17 & 16 & 11 & 24 & 19 & 7 & 13 & 5 & 8 & 9 & 12 \\
\hline $\mathrm{Zn}$ & 108 & 110 & 101 & 119 & 49 & 102 & 111 & 43 & 99 & 58 & 64 & 42 & 78 \\
\hline $\mathrm{Rb}$ & 363 & 348 & 378 & 406 & 299 & 388 & 284 & 268 & 306 & 415 & 564 & 457 & 600 \\
\hline $\mathrm{Sr}$ & 78 & 74 & 98 & 81 & 36 & 84 & 61 & 102 & 60 & 13 & 25 & 29 & 29 \\
\hline $\mathrm{Y}$ & 10 & 20 & 14 & 9 & 10 & 14 & 17 & 7 & 19 & 5 & 9 & 5 & 7 \\
\hline $\mathrm{Zr}$ & 127 & 209 & 143 & 197 & 86 & 194 & 181 & 66 & 180 & 42 & 77 & 78 & 95 \\
\hline $\mathrm{Nb}$ & 18 & 16 & 20 & 20 & 14 & 16 & 16 & 10 & 13 & 18 & 21 & 18 & 25 \\
\hline $\mathrm{Sn}$ & 14 & 10 & 20 & 7 & 13 & 10 & 17 & 21 & 17 & 27 & 53 & 45 & 67 \\
\hline $\mathrm{Cs}$ & 24.7 & 21.0 & 32.3 & 10.1 & 25.8 & 15.2 & 25.7 & 15.2 & 31.2 & 35.3 & 54.4 & 27.7 & 38.0 \\
\hline $\mathrm{Ba}$ & 352 & 426 & 430 & 488 & 163 & 387 & 278 & 1090 & 329 & 45 & 77 & 122 & 136 \\
\hline $\mathrm{Ta}$ & 2.1 & 1.6 & 2.9 & 2.0 & 2.2 & 1.4 & 2.0 & 1.3 & 2.3 & 3.9 & 4.8 & 3.0 & 4.5 \\
\hline W & 3 & 2 & 3 & 1 & 3 & 5 & 3 & 1 & 2 & 4 & 7 & 11 & 13 \\
\hline $\mathrm{T} 1$ & 4.0 & 3.1 & 3.8 & 4.1 & 2.8 & 3.5 & 2.5 & 2.0 & 2.8 & 4.1 & 7.0 & 4.4 & 4.8 \\
\hline $\mathrm{Bi}$ & 0.9 & 0.8 & 1.0 & 1.0 & 2.4 & 0.8 & 1.5 & 0.6 & 2.3 & 3.0 & 4.7 & 16.8 & 46.4 \\
\hline $\mathrm{Th}$ & 19.7 & 44.0 & 23.9 & 41.5 & 10.5 & 38.4 & 14.3 & 5.4 & 21.4 & 3.3 & 18.1 & 10.7 & 13.9 \\
\hline $\mathrm{U}$ & 10.7 & 10.7 & 7.9 & 12.6 & 10.3 & 14.2 & 6.9 & 3.5 & 8.0 & 8.4 & 9.3 & 19.2 & 12.5 \\
\hline $\mathrm{F}$ & 998 & 677 & 1345 & 1309 & 1154 & 1280 & 493 & 583 & 420 & 1602 & 4184 & 2947 & 4595 \\
\hline $\mathrm{Li}$ & 142 & 155 & 224 & 91 & 155 & 99 & 183 & 64 & 174 & 250 & 436 & 252 & 347 \\
\hline $\mathrm{La}$ & 33.2 & 49.7 & 27.6 & 37.6 & 17.8 & 49.2 & 30.8 & 12.0 & 29.4 & 4.8 & 19.1 & 13.9 & 20.8 \\
\hline $\mathrm{Ce}$ & 69.3 & 108 & 60.8 & 84.4 & 37.8 & 112 & 65.4 & 24.2 & 63.1 & 10.2 & 42.0 & 31.8 & 45.4 \\
\hline $\operatorname{Pr}$ & 7.81 & 13.3 & 7.19 & 10.9 & 4.29 & 12.2 & 8.05 & 2.83 & 7.77 & 1.24 & 4.69 & 3.37 & 5.65 \\
\hline $\mathrm{Nd}$ & 30.5 & 50.2 & 26.9 & 41.7 & 16.9 & 48.2 & 30.4 & 10.6 & 30.2 & 4.9 & 17.9 & 12.9 & 20.8 \\
\hline Sm & 6.1 & 10.7 & 5.9 & 8.7 & 3.8 & 10.0 & 6.6 & 2.3 & 6.2 & 1.3 & 4.2 & 3.1 & 5.1 \\
\hline $\mathrm{Eu}$ & 0.67 & 0.86 & 0.58 & 0.56 & 0.42 & 0.58 & 0.79 & 0.35 & 0.69 & 0.12 & 0.21 & 0.25 & 0.37 \\
\hline $\mathrm{Gd}$ & 4.8 & 7.3 & 4.3 & 5.2 & 3.4 & 6.6 & 4.9 & 1.8 & 4.9 & 1.2 & 3.3 & 2.1 & 3.5 \\
\hline $\mathrm{Tb}$ & 0.6 & 1.0 & 0.7 & 0.6 & 0.5 & 0.8 & 0.7 & 0.3 & 0.8 & 0.2 & 0.4 & 0.3 & 0.5 \\
\hline Dy & 2.6 & 4.4 & 2.9 & 2.3 & 2.3 & 3.0 & 3.4 & 1.4 & 3.7 & 1.0 & 1.9 & 1.2 & 1.8 \\
\hline Ho & 0.4 & 0.7 & 0.5 & 0.3 & 0.4 & 0.5 & 0.6 & 0.2 & 0.6 & 0.2 & 0.3 & 0.2 & 0.2 \\
\hline $\mathrm{Er}$ & 0.9 & 1.8 & 1.2 & 0.8 & 1.0 & 1.3 & 1.6 & 0.6 & 1.7 & 0.5 & 0.8 & 0.5 & 0.6 \\
\hline $\mathrm{Tm}$ & 0.12 & 0.26 & 0.17 & 0.11 & 0.14 & 0.16 & 0.24 & 0.10 & 0.26 & 0.08 & 0.12 & 0.07 & 0.09 \\
\hline $\mathrm{Yb}$ & 0.7 & 1.6 & 1.0 & 0.7 & 0.8 & 1.0 & 1.5 & 0.6 & 1.6 & 0.6 & 0.7 & 0.5 & 0.6 \\
\hline $\mathrm{Lu}$ & 0.11 & 0.22 & 0.14 & 0.10 & 0.11 & 0.14 & 0.22 & 0.08 & 0.23 & 0.08 & 0.10 & 0.07 & 0.08 \\
\hline $\mathrm{Eu} / \mathrm{Eu}^{*}$ & 0.38 & 0.30 & 0.35 & 0.25 & 0.36 & 0.26 & 0.43 & 0.52 & 0.39 & 0.31 & 0.18 & 0.30 & 0.21 \\
\hline Lan/Smn & 3.4 & 2.9 & 2.9 & 2.7 & 3.0 & 3.1 & 3.0 & 3.3 & 3.0 & 2.4 & 2.9 & 2.9 & 2.7 \\
\hline REE total & 537.38 & 864.01 & 488.96 & 650.42 & 321.66 & 808.85 & 556.67 & 208.05 & 544.26 & 104.36 & 331.82 & 239.09 & 152.74 \\
\hline
\end{tabular}

A complete dataset is available on request. 


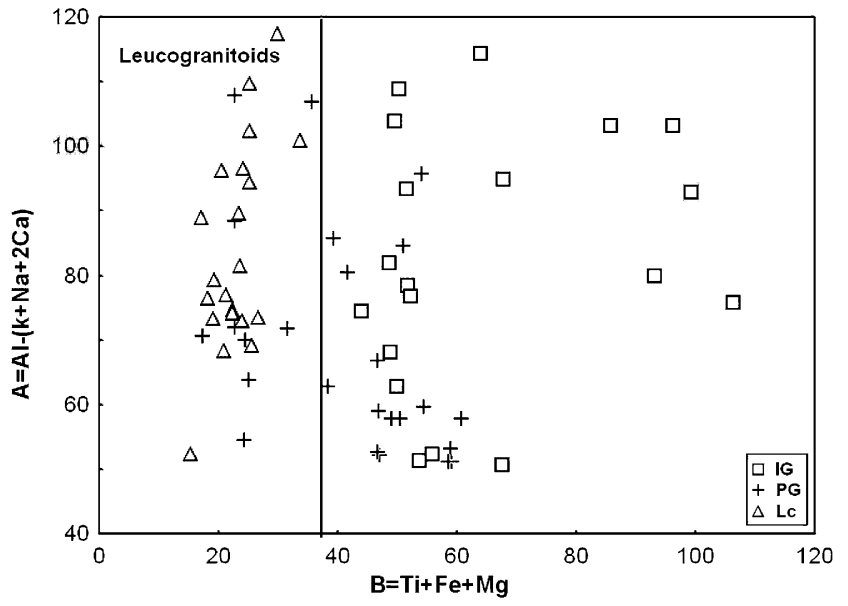

Fig. 3. Variation diagram of A versus B (see Debon and Le Fort, 1988) for the Jálama batholith granite units.

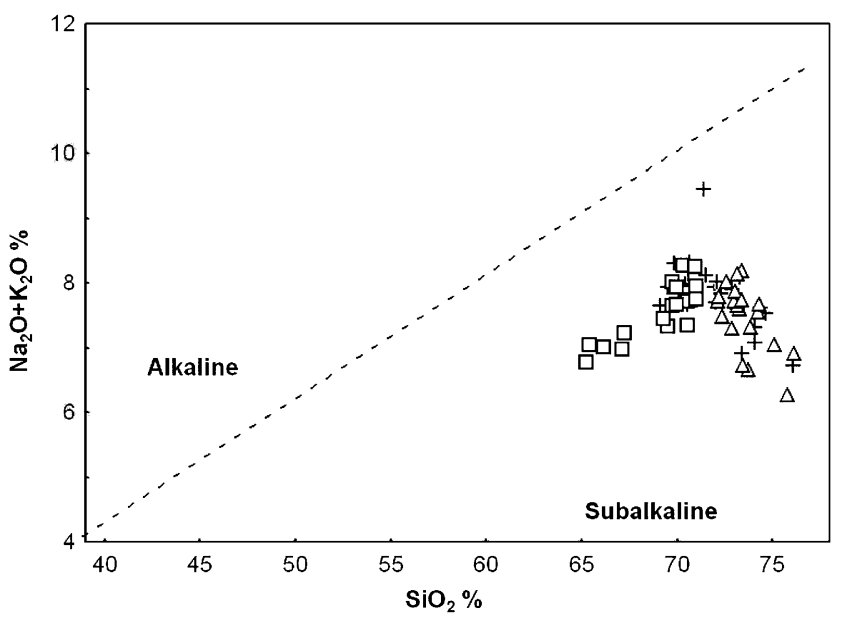

Fig. 4. $\left(\mathrm{Na}_{2} \mathrm{O}+\mathrm{K}_{2} \mathrm{O}\right)$ versus $\mathrm{SiO}_{2}$.

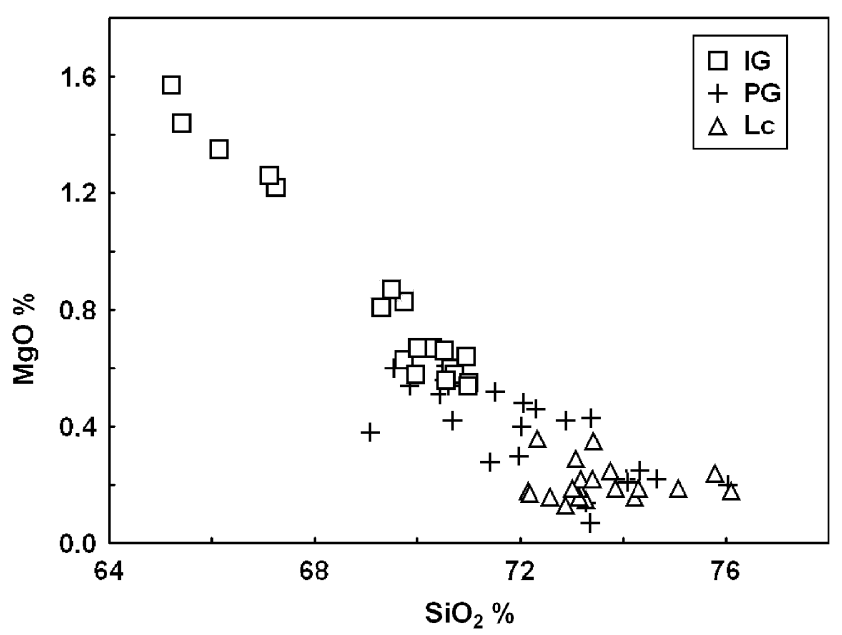

Fig. 5. Harker variation diagrams of $\mathrm{MgO}$ versus $\mathrm{SiO}_{2}$.
In the leucogranites the content of LREE and for HREE is less than that of the other granite units.

\section{Geochemistry of the granites of Jálama}

\section{Two-mica inhomogeneous granitoids}

A total of 19 samples were collected from this granitic unit. We have already explained, on describing this facies in Section 3, that two subfacies can be distinguished in this, according to whether they are rich or poor in restites, with different petrographic characteristics. And so, in the variation diagram (Fig. 5) two groups of samples of inhomogeneous granitoids can be seen with a perfect concordance corresponding to each subfacies. The restite-rich samples exhibit a low content of silica $(65.2-67.2 \%)$ and greater content of $\mathrm{Al}_{2} \mathrm{O}_{3}$, $\mathrm{Fe}_{2} \mathrm{O}_{3}, \mathrm{TiO}_{2}$ and $\mathrm{MgO}$ than the restite-poor samples, with greater percentages in silica $(69.3-71.1 \%) . \mathrm{P}_{2} \mathrm{O}_{5}$ is present with an average value of $0.4 \%$, being the facies poor in restites which has the greater concentration of $\mathrm{P}_{2} \mathrm{O}_{5}$. The content of $\mathrm{Ba}$ is greater in the restite-rich subfacies and decrease with the $\mathrm{SiO}_{2}$ content. The content of $\mathrm{Li}, \mathrm{F}, \mathrm{Rb}, \mathrm{Sn}, \mathrm{W}$ and $\mathrm{Ta}$ are similar, in the restite-rich subfacies as in the poor (Fig 6). The ratio $\mathrm{K} / \mathrm{Na}$ is always $>1$ for both subfacies.

\section{Two-mica porphyritic granites-monzogranites}

A total of 26 samples were collected from this extensive facies. The contents of silica vary between $69.1 \%$ and $76.0 \%$ the average being $71.9 \%$. The highest values in $\mathrm{SiO}_{2}$ correspond in general to the zones nearest to the margin of the batholith. The values of $\mathrm{Al}_{2} \mathrm{O}_{3}$ vary between $12.52 \%$ and $16.29 \%$. $\mathrm{CaO}$ exhibits an average content of less than $1 \% . \mathrm{Fe}_{2} \mathrm{O}_{3}, \mathrm{TiO}_{2}$ and $\mathrm{MgO}$ are contained in biotite mainly, which average value of the sum, of being $2.9 \%$. In the Harker diagram for $\mathrm{MgO}$ (Fig 5) the trend is dominated by the content of biotite, given that the $\mathrm{Mg}$ is mainly contained in this silicate or in the restites. The biotite is mixed as solid crystals in the melt. $\mathrm{Zr}$ is mainly contained in zircon and most of the zircon is included in biotite, whose behaviour indirectly controls this accessory phase. $\mathrm{P}_{2} \mathrm{O}_{5}$ exhibits an average value of $0.4 \%$. The ratio $\mathrm{K} / \mathrm{Na}$ is always $>1$. The value of Ba decreases with the content of silica, insofar as the subfacies of the margins of the porphyritic granites exhibit a lower content in this element (Fig. 6).

The values of $\mathrm{Li}, \mathrm{F}, \mathrm{Rb}, \mathrm{Sn}, \mathrm{W}$, and Ta (Fig. 6) tend to increase with the $\mathrm{SiO}_{2}$ content and, as such, are higher in the subfacies of the margin.

\section{Leucogranites}

A total of 21 samples were collected of leucogranites. The contents of silica vary between $72.1 \%$ and $76.1 \%$, the average being $73.5 \%$. The values of $\mathrm{Al}_{2} \mathrm{O}_{3}$ vary between $13.5 \%$ and $15.4 \%$. CaO exhibits a moderate to 

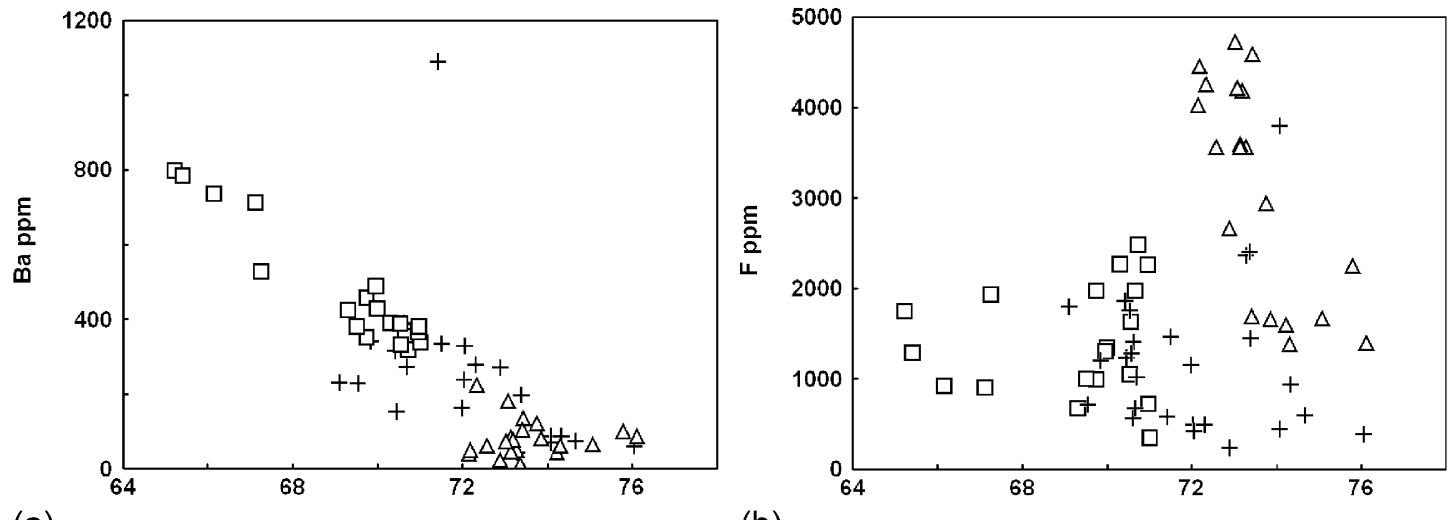

(a)

$\mathrm{SiO}_{2} \%$

(b)
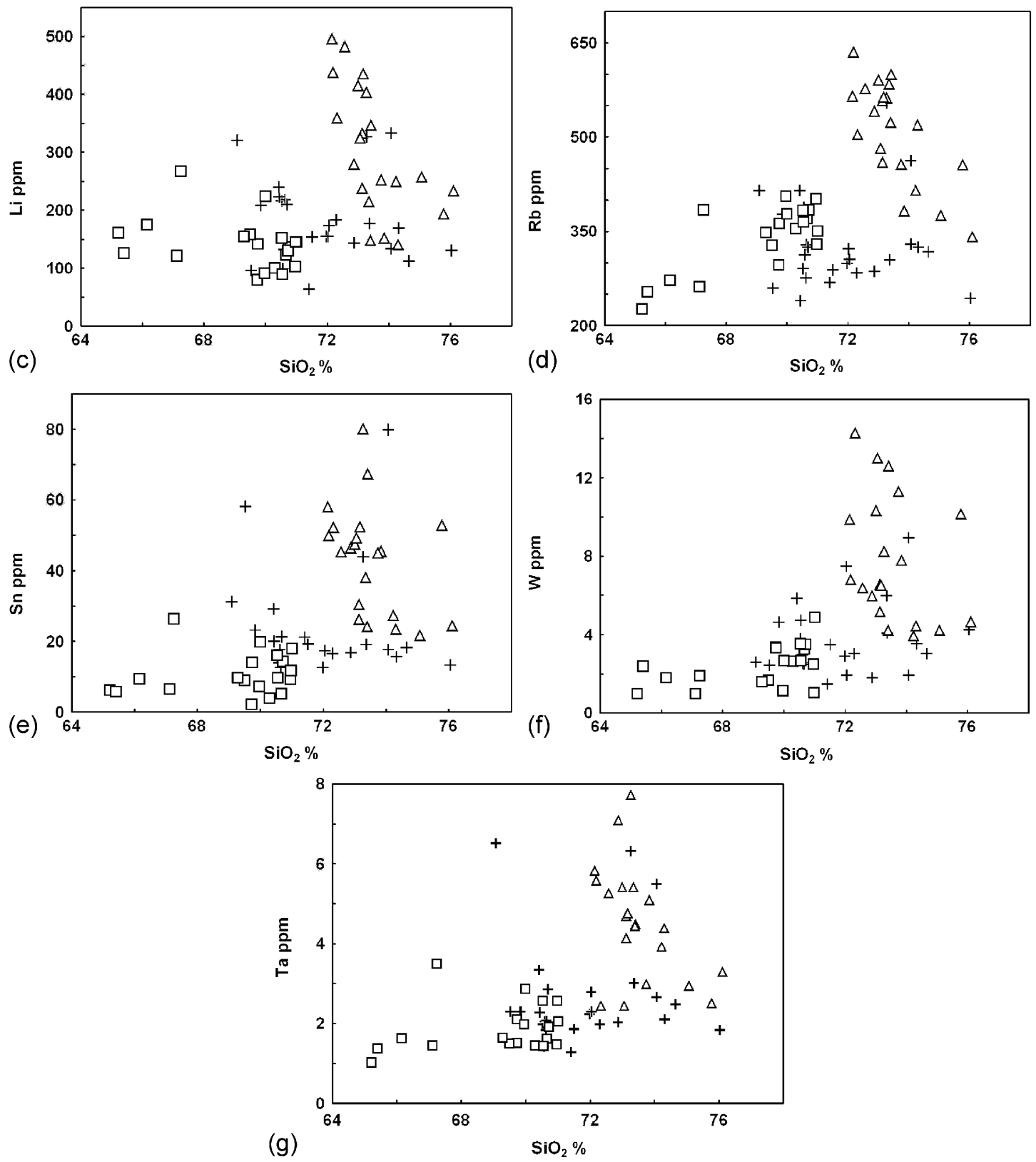

Fig. 6. Harker variation diagrams of selected trace element of the Jálama batholith granites (symbols as in Fig. 5). 


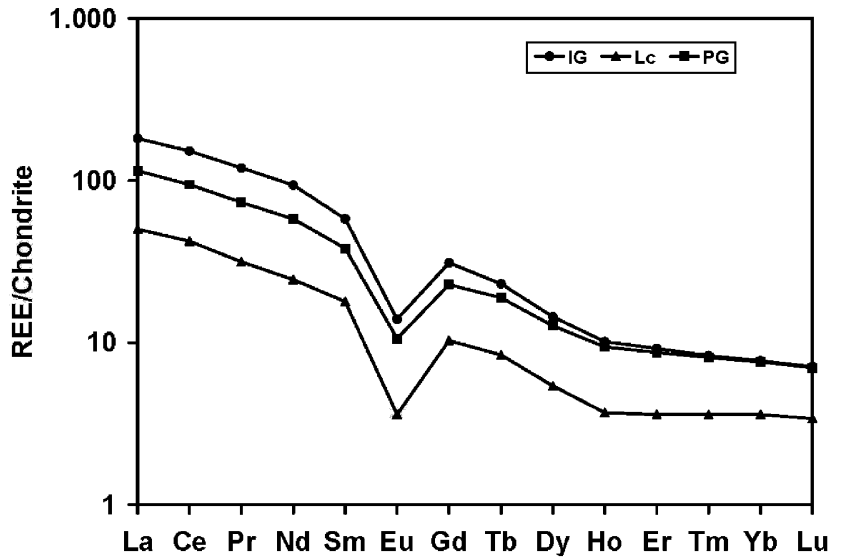

Fig. 7. Average chondrite-normalised REE abundances of granites from the Jálama batholith.

low concentration, values between $0.2 \%$ and $0.5 \%$, the average value being $0.3 \% . \mathrm{Fe}_{2} \mathrm{O}_{3}, \mathrm{TiO}_{2}$ and $\mathrm{MgO}$, the average value of the sum of these three oxides being $1.6 \% . \mathrm{P}_{2} \mathrm{O}_{5}$ shows an average value of $0.4 \%$. The ratio $\mathrm{K} / \mathrm{Na}$ is always $>1$.

The leucogranites exhibit low concentrations in compatible elements such as Ba and Eu (Figs. 6 and 7) contained in the feldspars as a result of which the fractionation of these produces the depletion of the Ba.

$\mathrm{Ba}$ versus $\mathrm{SiO}_{2}$ diagram (Fig. 6) shows that the same parent magma cannot have originated by direct differentiation of the three groups of granites. On the contrary, it separates the leucogranites from the other granite units.

The leucogranites are rich in incompatible elements such as Li, F, Rb, Sn, W and Ta, all of which vary for the same content of silica (Table 2; Fig. 6). These patterns indicate that they have been generated by liquids segregated after a significant fractionation crystallisation process. This fractionation process is superimposed on the genesis of the two-mica porphyritic granites-monzogranites.

\section{Geochronology}

To determine the ages of emplacement of the principal granites of the Jálama batholith, the isotopic ratios ${ }^{87} \mathrm{Rb} /{ }^{86} \mathrm{Sr}$ and ${ }^{87} \mathrm{Sr} /{ }^{86} \mathrm{Sr}$ were analysed in seven samples of inhomogeneous granitoids and seven samples of porphyritic granites (Table 3). The samples of the inhomogeneous granitoids define an isochron in the diagram ${ }^{87} \mathrm{Sr} /{ }^{86} \mathrm{Sr}$ versus ${ }^{87} \mathrm{Rb} /{ }^{86} \mathrm{Sr}$ which gives an age of $319 \pm 10 \mathrm{Ma}(1 \sigma)$. The value of MSWD for this isochron is 0.1935839 and an initial ratio ${ }^{87} \mathrm{Sr} /{ }^{86} \mathrm{Sr}=$ $0.711 \pm 0.001 \quad(1 \sigma) \quad$ (Fig. 8a). The samples of the porphyritic granites define an isochron (Fig. 8b) which gives an age of $279 \pm 9 \mathrm{Ma}(1 \sigma)$. The value of MSWD for
Table 3. $\mathrm{Rb}-\mathrm{Sr}$ isotopic data of the Jaláma batholith granitic units

\begin{tabular}{cllcll}
\hline Sample & Facies & $\mathrm{Rb}(\mathrm{ppm})$ & $\mathrm{Sr}(\mathrm{ppm})$ & ${ }^{87} \mathrm{Rb} /{ }^{86} \mathrm{Sr}$ & ${ }^{87} \mathrm{Sr} /{ }^{86} \mathrm{Sr}$ \\
\hline 1 & IG & 370.9 & 78.6 & 14.711 & 0.778 \\
2 & IG & 354.5 & 88.6 & 12.43 & 0.766 \\
3 & IG & 384.4 & 76.2 & 15.827 & 0.783 \\
19 & IG & 361.2 & 52.8 & 20.769 & 0.805 \\
28 & IG & 402.4 & 85.9 & 13.919 & 0.774 \\
99 & IG & 297.0 & 126.9 & 6.053 & 0.738 \\
36 & IG & 329.4 & 384.3 & 11.771 & 0.765 \\
5 & PG & 290.6 & 71.9 & 12.269 & 0.768 \\
6 & PG & 288.7 & 60.9 & 14.385 & 0.776 \\
7 & PG & 275.8 & 72.7 & 11.24 & 0.764 \\
9 & PG & 585.0 & 37.8 & 56.078 & 0.941 \\
26 & PG & 388.1 & 84.0 & 16.295 & 0.783 \\
35 & PG & 313.1 & 71.1 & 15.633 & 0.783 \\
38 & PG & 283.7 & 61.3 & 12.892 & 0.767 \\
\hline
\end{tabular}

this isochron is 0.289 and an initial ratio ${ }^{87} \mathrm{Sr} /{ }^{86} \mathrm{Sr}=0.719 \pm 0.001(1 \sigma)$.

\section{Mineralisation potential of granitic units of the Jálama batholith}

In the Jalama batholith, the Sn mineralisation is basically present in the form of cassiterite in intragranitic quartz veins, some of which gave rise to mining operations of some importance in the last century. Of lesser importance are the disseminations of accessory cassiterite in aplitic or microgranitic zones.

Based on observation in the field of mineral occurrences and old workings of Sn in the Jálama batholith, it has been shown that this $\mathrm{Sn}$ mineralisation is associated with the leucogranites and the subfacies at the margin of the porphyritic granites. On the contrary, the internal porphyritic granites and the inhomogeneous granitoids do not show mineralisation.

As the mineralisation is not regularly distributed, geochemical criteria are applied that may be useful in the determination of the mineralising potential; that is to say, with a capacity to host Sn-mineralisation. This allows us to determine if the mineralised facies of the Jálama batholith fulfils the corresponding geochemical criteria.

Table 4 shows the ranges and the average concentrations of the trace elements selected in the different granites of the Jalama batholith as indicators of the mineralisation potential.

\section{Tin and tungsten}

The abundance of $\mathrm{Sn}$ is one of the most widely used to distinguish between Sn-bearing granites and non-miner- 

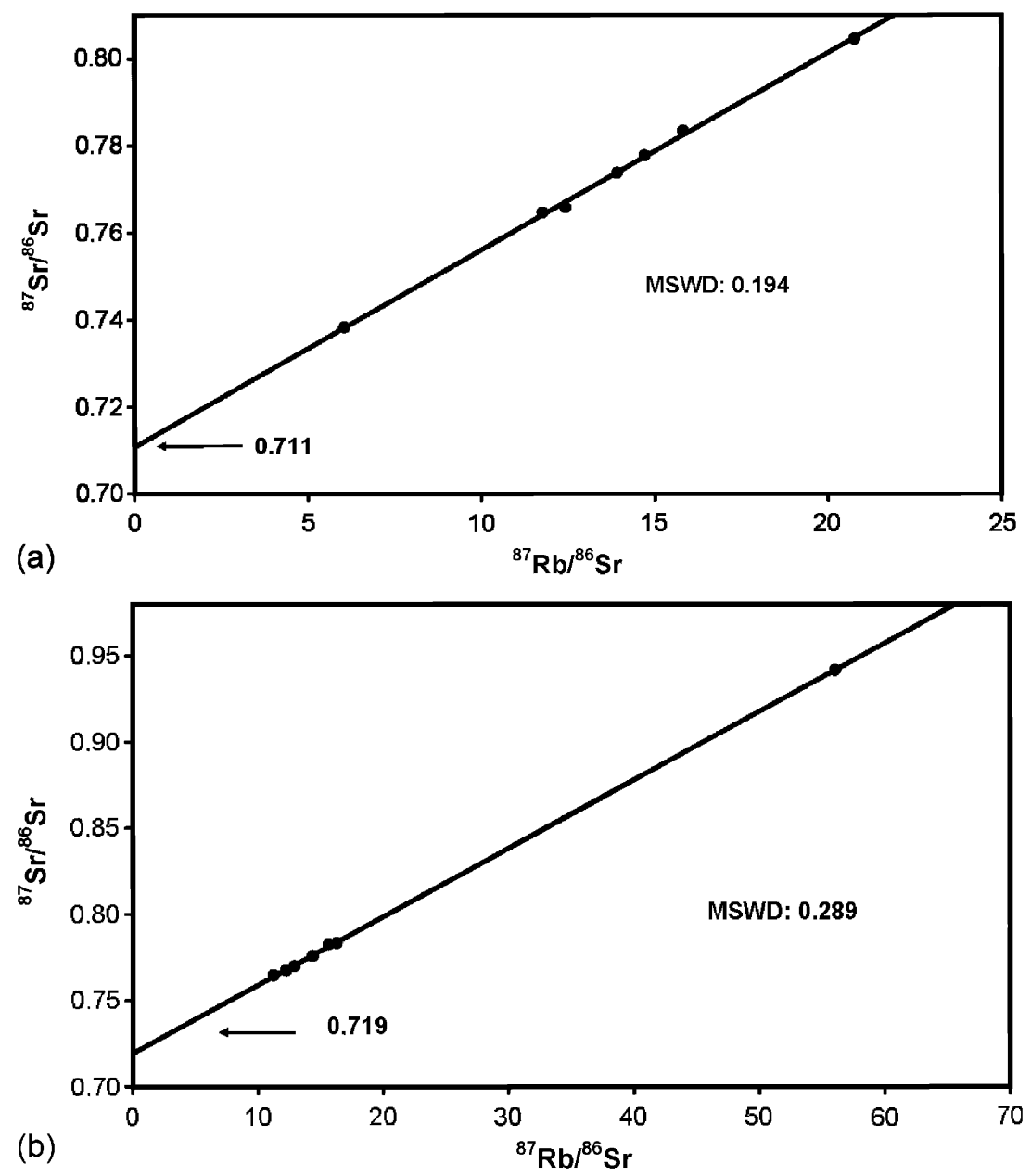

Fig. 8. ${ }^{87} \mathrm{Rb} /{ }^{86} \mathrm{Sr}$ versus ${ }^{87} \mathrm{Sr} /{ }^{86} \mathrm{Sr}$ isochron diagram for whole-rock of (a) inhomogeneous granitoids. and (b) porphyritic granites, of the Jálama batholith.

Table 4. Chemical analyses (in ppm) and average contents of mineralisation potential indicator elements of Jaláma batholith granite

\begin{tabular}{|c|c|c|c|c|c|c|}
\hline & \multicolumn{2}{|l|}{ IG } & \multicolumn{2}{|l|}{ PG } & \multicolumn{2}{|l|}{$\mathrm{Lc}$} \\
\hline & \multicolumn{2}{|l|}{$n=19$} & \multicolumn{2}{|l|}{$n=26$} & \multicolumn{2}{|c|}{$n=20$} \\
\hline & Mean & Range & Mean & Range & Mean & Range \\
\hline $\mathrm{Sn}$ & 11 & $2-26$ & 25 & $10-80$ & 44 & $22-80$ \\
\hline W & 2 & $1-5$ & 4 & $1-9$ & 8 & $4-14$ \\
\hline $\mathrm{Rb}$ & 340 & $226-406$ & 327 & $140-510$ & 506 & $341-636$ \\
\hline $\mathrm{Li}$ & 135 & $80-224$ & 180 & $64-333$ & 309 & $141-496$ \\
\hline $\mathrm{Zr}$ & 188 & $126-269$ & 128 & $34-23$ & 62 & $39-114$ \\
\hline $\mathrm{Ba}$ & 454 & $319-784$ & 244 & $42-439$ & 86 & $23-225$ \\
\hline $\mathrm{Sr}$ & 111 & $71-217$ & 57 & $18-115$ & 25 & $13-50$ \\
\hline $\mathrm{F}$ & 1413 & $350-2485$ & 1021 & $237-264$ & 3102 & $1382-4726$ \\
\hline
\end{tabular}

alised granites (Neiva, 1984; Lehmann, 1990). The content of $\mathrm{Sn}$ of the granites of Jálama (Table 4) increases from the inhomogeneous granitoids (11 ppm), passing through the porphyritic granites $(25 \mathrm{ppm})$ to the leucogranites $(44 \mathrm{ppm})$. Given that the average $\mathrm{Sn}$ content for normal granites is $4.3 \mathrm{ppm}$ (Tischendorf, 1977) all the granitic units of Jálama are rich in Sn. The concentrations in $\mathrm{W}$ are very similar for both the inhomogeneous granitoids and the porphyritic granites (Table 4). Towards the more leucocratic regions, these values are higher, the greatest concentration of $\mathrm{W}$ being in the leucogranites.

\section{Rubidium, lithium, zirconium, barium, strontium and fluorine}

The enrichment of certain elements such as $\mathrm{Rb}, \mathrm{Li}, \mathrm{F}$, and impoverishment of others such as $\mathrm{Zr}, \mathrm{Ba}$, Sr may be an indication of mineralisation in granitic rocks (Beus and Gregorian, 1975; Haapala, 1977). The larger contents of $\mathrm{Rb}, \mathrm{F}$ and $\mathrm{Li}$ (Table 4 ) correspond to the leucogranites, whereas in the inhomogeneous granitoids and in the porphyritic granites, they are similar, but at a 


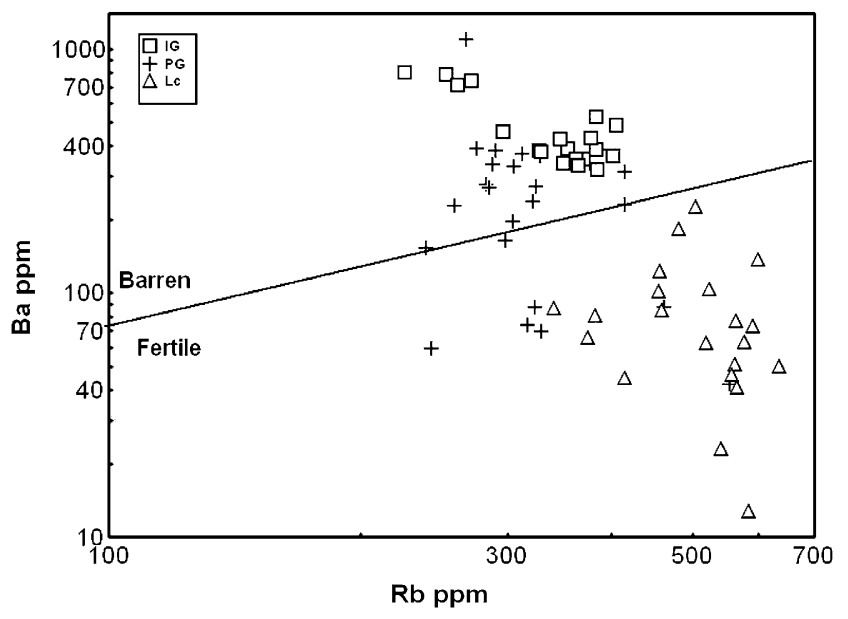

Fig. 9. Plot of $\mathrm{Ba}$ versus $\mathrm{Rb}$ for the Jálama batholith granites (symbols as in Fig. 5).

lower level. $\mathrm{Zr}$, Ba and $\mathrm{Sr}$ show concentrations relatively higher in inhomogeneous granitoids and porphyritic granites (Table 4) and, conversely, are impoverished in the leucogranites.

The ratios between some of the elements mentioned above $(\mathrm{Ba} / \mathrm{Rb}, \mathrm{K} / \mathrm{Rb}, \mathrm{Sr} / \mathrm{Rb})$, as in the diagrams $\mathrm{Ba}-\mathrm{Rb}, \mathrm{K}-\mathrm{Rb}$ and $\mathrm{Sr}-\mathrm{Rb}$, have been often used to distinguish mineralised granites from barren granites (Tauson and Kozlov, 1973; Dall Agnol et al., 1984; Dall Agnol et al., 1994). This application is based on the differences in the migration characteristics of related elements during magmatic and post-magmatic processes (Olade, 1980).

The $\mathrm{Ba}$ versus $\mathrm{Rb}$ diagram separates by a line of slope 0.5 the barren granites from the fertile ones (Fig. 9). Projecting the values of these elements for the different granites of the Jálama batholith gives the following result: the leucogranites and the subfacies at the margin of the porphyritic granites are projected into an area of the diagram of the fertile granites. On the contrary, the internal porphyritic granites and the inhomogeneous granitoids are projected into an area of the sterile granites. $\mathrm{Rb}$ shows enrichment in the leucogranites, whereas the reverse is true for $\mathrm{Ba}$ (Table 4). Given that the $\mathrm{Sn}$ mineralisation is observed over the terrain associated with the leucogranites and the subfacies at the margin of the porphyritic granites, one can affirm that low $\mathrm{Ba} / \mathrm{Rb}$ ratios (Fig. 9) characterise those granites of Jálama with mineralisation potential.

Likewise, low $\mathrm{K} / \mathrm{Rb}$ ratios $(<100)$ characterise the stanniferous and mineralised granites (Tischendorf, 1977; Olade, 1980). Projecting again the samples of the Jálama batholith in the diagram $\mathrm{K}$ versus $\mathrm{Rb}$ (Fig. 10), the line of slope 100 clearly separates the leucogranites from the inhomogeneous granitoids. The majority of the porphyrytic granites fall within the field of the sterile granites, except the porphyrytic granites at the edge of

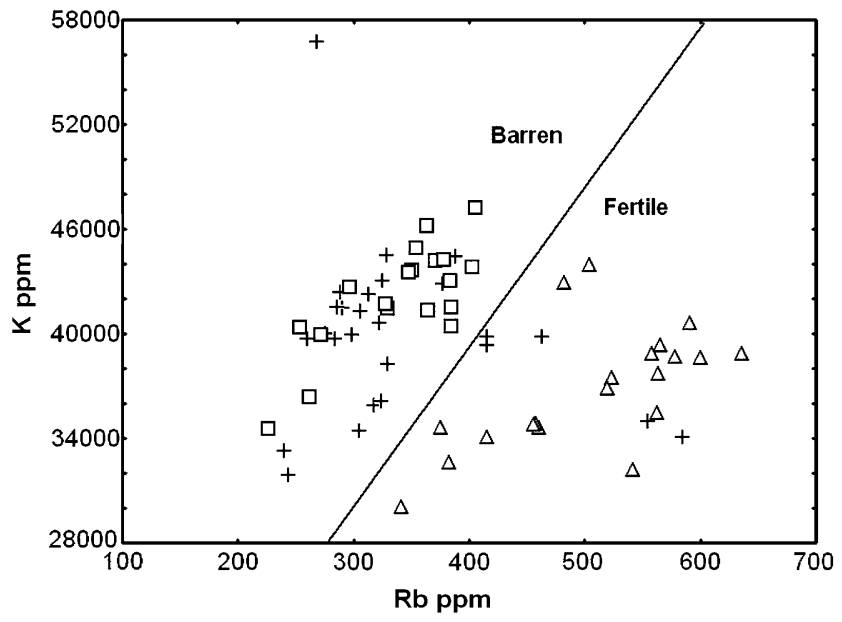

Fig. 10. Plot of $\mathrm{K}$ versus $\mathrm{Rb}$ for the Jálama batholith granites (symbols as in Fig. 5).

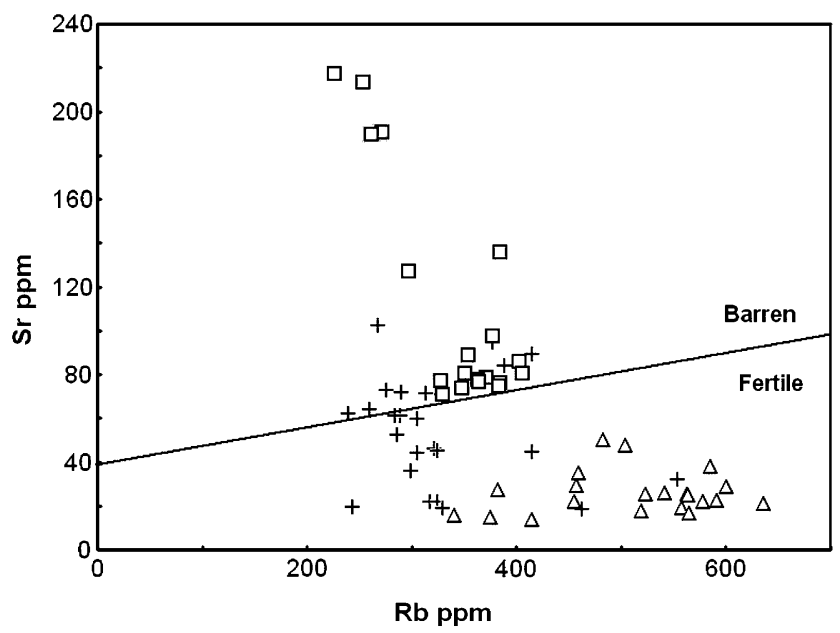

Fig. 11. Plot of Sr versus $\mathrm{Rb}$ for the Jálama batholith granites (symbols as in Fig. 5).

the batholith which are mineralised as can be seen in the field and in Fig. 10 are projected in an area of the fertile granites. As such, low $\mathrm{K} / \mathrm{Rb}$ ratios $(<100)$ characterise those granites of the Jálama batholith with a capacity to host Sn-mineralisation.

Similar information, in terms of mineralisation potential, is provided by the $\mathrm{Sr}$ versus $\mathrm{Rb}$ diagram (Fig. 11). The line of slope 0.1 separates the sterile granites from the fertile ones, leaving the leucogranites and the subfacies at the margin of the porphyritic granites projected in the lower field of the diagram, which means that they exhibit low $\mathrm{Sr} / \mathrm{Rb}$ ratios.

\section{Thorium and phosphorous}

The most recent findings on the mineralising potential are based on a study of the content in radioelements and 


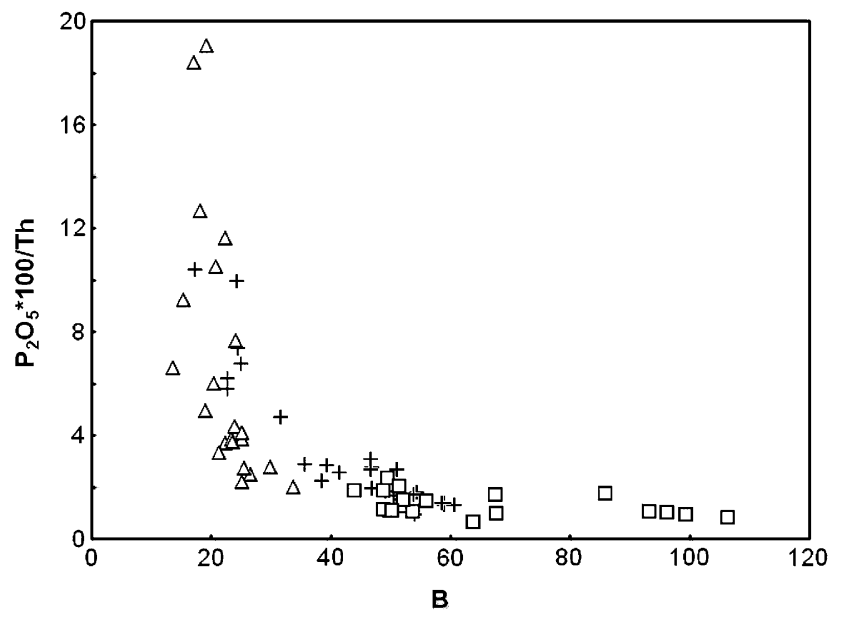

Fig. 12. Plots $\mathrm{P}_{2} \mathrm{O}_{5}{ }^{*} 100 / \mathrm{Th}$ versus $\mathrm{B}(\mathrm{B}=\mathrm{Ti}+\mathrm{Fe}+\mathrm{Mg})$ for the Jálama batholith granites (symbols as in Fig. 5).

in $\mathrm{P}$, brought to light by Scheepers (2000), who uses the diagram $\mathrm{P}_{2} \mathrm{O}_{5} * 100 / \mathrm{Th}$ vs. $\mathrm{B} \quad(\mathrm{B}=\mathrm{Ti}+\mathrm{Fe}+\mathrm{Mg})$ to distinguish between barren granites and mineralised granites. According to this author, mineralised S-type granites are extremely enriched in $\mathrm{P} / \mathrm{Th}$ and follow an evolutionary line more or less parallel to the $Y$-axis on such a diagram, contrasting with barren granites of the same type. The projection of the samples of the Jálama batholith in this diagram (Fig. 12) shows that the leucogranites and the subfacies at the margin of the porphyritic granites are enriched in $\mathrm{P} / \mathrm{Th}$, in effect following an evolutionary line parallel to the $Y$-axis, all of which corresponds to zones with mineralisation on the ground. On the contrary, the internal porphyritic granites and the inhomogeneous granitoids, in which mineralisation has not been found, follow a line parallel to the $X$-axis (Fig. 12).

Many evolved peraluminous granites and their associated pegmatites have large contents of $\mathrm{P}_{2} \mathrm{O}_{5}$ (Bea et al., 1992; Broska et al., 2004). Granites associated with $\mathrm{Sn}, \mathrm{U}$ and $\mathrm{W}$ mineralisation in CIZ, usually have high phosphorus contents. Likewise, values of $\mathrm{P}_{2} \mathrm{O}_{5}>0.5 \mathrm{wt} \%$ at $\mathrm{SiO}_{2}>70 \mathrm{wt} \%$ are good indicators of economic mineralisation (Bea et al., 1992). In the Jalama batholith, contents greater than $70 \mathrm{wt} \%$ in $\mathrm{SiO}_{2}$ are found in the leucogranites and practically all the porphyritic granites, but not in the inhomogeneous granitoids which, taken together, have less than $70 \mathrm{wt} \%$ en $\mathrm{SiO}_{2}$. Insofar as the contents in $\mathrm{P}_{2} \mathrm{O}_{5}$ of the different established granites are concerned, the average values are somewhat less than $0.5 \mathrm{wt} \%$ by weight (Table 2).

\section{Discussion}

The Jalama batholith has been included among the Araya-type granites these being emplaced in the epizonal domain of the CIZ; they are generally allochthonous, post-kinematic, zoned; they have important volumes of leucocratic differentiates, they are enriched en $\mathrm{P}$, they exhibit small quantities of restitic material and can be mineralised $(\mathrm{Sn}, \mathrm{W} \pm \mathrm{U} \pm \mathrm{Li} \pm \mathrm{P}$ ) (Corretgé et al., 1985; Bea et al., 1987; Ramírez and Menéndez, 1999).

The granites of the Jálama batholith correspond to peraluminous and subalkaline rocks, with elevated contents of $\mathrm{P}$ and $\mathrm{F}$. Li, $\mathrm{Rb}, \mathrm{Sn}$ and $\mathrm{W}$ tend to increase with the $\mathrm{SiO}_{2}$ content. They exhibit a high $\mathrm{K} / \mathrm{Na}$ ratio, high normative corundum, A/CNK $>1.1,\left(\mathrm{Sr}^{87} / \mathrm{Sr}^{86}\right)_{0}>$ 0.707 and values of $\mathrm{Th}+\mathrm{U}<50 \mathrm{ppm}$ which are characteristics belonging to the S-type granites (Chappell and White, 1974; White and Chappell, 1988; Scheepers, 2000; Clemens, 2003). The high content of $\mathrm{P}_{2} \mathrm{O}_{5}$ in $\mathrm{S}$-granites is consistent with their peraluminic composition (Chappell, 1999), given that Montel et al. (1988) have demonstrated that apatite is soluble in peraluminic melts.

Of the three types of granites that have been characterised petrographically and geochemically, the inhomogeneous granitoids and the porphyritic granites are less peraluminic, more mafic and rich in $\mathrm{CaO}$ and the ratio $\mathrm{K} / \mathrm{Na}$ is higher than in the leucogranites. There is a certain overlap between the porphyritic granites and the leucogranites with respect to the contents of trace elements, but never between the inhomogeneous granitoids and the leucogranites.

The leucogranites show a decrease in anorthite content of plagioclase, with quartz and muscovite dominant, which suggests a crystal fractionation model. The leucogranites have been generated by fractional crystallisation of early mineral phases, principally biotite, with the accessory minerals included in it and in the plagioclase. In the leucogranites the ratio $\mathrm{K} / \mathrm{Na}$ is lower than in the porphyritic granites. This characteristic corresponds to derivative liquids produced from fractional crystallisation, as obtained experimentally by Scaillet et al. (1995)

The genesis of these granitic units has not been produced by sequential partial melting given that the magmas in that case evolve progressively to more mafic ones, something which has not happened here.

From the field data (mainly the presence of intrusive contacts), the petrographic characteristics (especially the mineralogical and textural) and lack of geochemical affinity relationships between the inhomogeneous granitoids and the porphyritic granites and the leucogranites, indicate unrelated or independent magma batches and superimposed for the leucogranites, by a pulse crystal fractionation process.

Within a similar model of the distribution of the REE, with subparallel REE patterns in the types of granites established, the greater differences correspond to the leucogranites. These exhibit an exaggerated negative 
anomaly in Eu (Fig. 7) and total content of REE, as much in LREE as in HREE, lower than in the other units of the batholith (Table 2). This fact can be attributed to the fractionation of accessory minerals, such as apatite and zircon, which not only control the REE, but also the $\mathrm{P}$ and $\mathrm{Zr}$ (Watson, 1985; Watt and Harley, 1993; Ayres and Harris, 1997) and/or the mobilisation of the REE towards late hydrothermal fluids which carry Cl-REE and F-REE complexes (Flynn and Burnham, 1978; Taylor et al., 1981; Irber, 1999; Förster, 2001). All of which is in agreement with a process of fractional crystallisation superimposed on the leucogranites.

The ages obtained for the more important granite units, inhomogeneous granitoids and porphyritic granites, indicate an early intrusion of the inhomogeneous granitoids $(319 \pm 10 \mathrm{Ma})$, followed in time by the porphyritic granites $(279 \pm 9 \mathrm{Ma})$. This concords with the observed field relations, where the inhomogeneous granitoids are cross-cut by the porphyritic granites. According to the structural characteristics and ages obtained for the more important granites of the Jálama batholith, this can be included among the late-postkinematic granites (315-270 Ma) using as criteria the last phase of ductile deformation, $\mathrm{D}_{3}$ (Capdevilla et al., 1973; Ferreira et al., 1987; Serrano Pinto et al., 1987; Neiva and Gomes, 2001). Most batholiths formed in this period are uniformly composed of peraluminous K-rich S-type granodiorites and granites (Bea et al., 2003), the Jálama batholith being a clear example of this type of granitic emplacement. The ages obtained for the Jálama batholith are similar to the dates obtained by Dias et al. (1998) in the north zone of Portugal within the CIZ (Syn-D ${ }_{3}, 313-319$ Ma and Post-D $3,280-296 \mathrm{Ma}$ ). Other dates obtained in the nearer zones indicate to us a plutonism concentrated in the interval of ages 323-284 Ma (Bea et al., 1994; Villaseca et al., 1995; Herreros, 1998).

The high initial ratio ${ }^{87} \mathrm{Sr} /{ }^{86} \mathrm{Sr}$ of the granites reflects a significant participation of the $\mathrm{Sr}$ derived from preexisting crustal material. This agreement with what has been established for granitoids of the CIZ of similar characteristics to the Jálama batholith, in which the source rocks are high-grade peraluminous metamorphics (metagreywackes, metapelites and orthogneisses) (Bea, 1985; Villaseca et al., 1998; Castro et al., 1999).

To distinguish the granitoids with mineralisation potential from barren ones, geochemical indicators have been used, such as $\mathrm{Rb}, \mathrm{Li}, \mathrm{F}, \mathrm{Zr}, \mathrm{Ba}$ and $\mathrm{Sr}$ proposed by different authors (Olade, 1980; Dall Agnol et al., 1984; Dall Agnol et al., 1994; Scheepers, 2000). Low values for the ratios $\mathrm{Ba} / \mathrm{Rb}, \mathrm{K} / \mathrm{Rb}$ and $\mathrm{Sr} / \mathrm{Rb}$ correspond to the fertile granites of Jálama, such us the leucogranites and the subfacies at the margin of the porphyritic granites.
The enrichment in metals in granitoids has been studied by Stone and Exley (1985). Strong (1985) explains the presence of $\mathrm{Sn}-\mathrm{W}$ and $\mathrm{Sn}-\mathrm{W}-\mathrm{U}$ mineralisation relating them with the high content of radioelements in the granites. Manning and Henderson (1984) found a strong correlation between the $\mathrm{W}$ and $\mathrm{P}$, as is manifest in veins rich in minerals of $\mathrm{Sn}-\mathrm{W}$ in the Hercynian granites of Europe (London, 1992). Likewise, Green and Watson (1982) have established the control of the $\mathrm{P}$ in the geochemistry of trace elements between the accessory phases and the melt.

Pagel (1981) and Friedrich and Cuney (1987), point out the importance of the $\mathrm{P}$ in the behaviour of $\mathrm{U}$ and Th in granitic magmas. The most recent findings on the mineralising potential brought to light by Scheepers (2000) are based on a study of the content in radioelements and in $\mathbf{P}$. The diagrams corresponding to Section 7 lead us to the same conclusion: the leucogranites and the subfacies of the margin of the porphyritic granites correspond to granites with mineralisation potential, and as such will be granites productive of $\mathrm{Sn}$ mineralisation. Internal porphyritic granites and the inhomogeneous granitoids correspond to barren granites.

The major Sn content of the porphyrytic granites and especially the leucogranites is probably due to the fact that the $\mathrm{Sn}$ is held by muscovite and it increases during differentiation mainly due to an increase in the amount of muscovite (Neiva et al., 2002). In the leucogranites, the contents of $\mathrm{Sn}$ and other elements such as F, Li and Ta exhibit relatively large variations for the same grade of differentiation (Fig. 6). From this, one can deduce that some leucogranites have been enriched in $\mathrm{Sn}$ with the differentiation, which is the normal evolutionary behaviour, while other leucogranites have been impoverished to a greater or lesser degree. This impoverishment in Sn could be due to an absence of homogenisation of the magma with segregation of the same from an aqueous melt enriched in Sn. This melt together with the elements with affinity for the same would precipitate together. The $\mathrm{F}$ is one of those elements, which has a direct relation with the deposition of Sn. As a consequence, there would be an impoverishment of these elements in the last stages of the magmatic consolidation. In these processes with high activity of $\mathrm{H}_{2} \mathrm{O}$, evolved magmas predominate in which there is exsolution of aqueous fluid, and the aforementioned elements are those which are concentrated in the aqueous phase (Candela, 1995; Dunbar et al., 1996). Firstly there would be a concentration of the residual fluids carrying the $\mathrm{Sn}$ and forming disseminated mineralisation and subsequently they would become concentrated quartz veins with $\mathrm{Sn}$ mineralisation. In the sequence inhomogeneous granitoids-porphyritic granites-leucogranites, the process would culminate with the final precipitation of the $\mathrm{Sn}$ mineralisation. 
Finally, it can be shown that the most important mineralisation, which correspond to quartz veins with $\mathrm{Sn}$, are located in the leucogranites and in the subfacies at the margin of the porphyritic granites of the $\mathrm{N}$ zone. This confirms that the criteria established to distinguish granitoids with mineralisation potential from barren ones have been effective. In our opinion, they are valid not only for the Jálama batholith, but in a general way for the CIZ.

\section{Conclusions}

(1) In the granite batholith of Jálama, we can distinguish three types of granite from the petrographic and geochemical characterisation: inhomogeneous granitoids, porphyritic granites and leucogranites. The inhomogeneous granitoids are two-mica granites. The porphyritic granites, of variable porphyritic character, have somewhat more muscovite and less biotite than the inhomogeneous granitoids. The leucogranites have a medium to fine grain size, with a high content of muscovite.

(2) All the differentiated granite units are peraluminous and subalkaline, with elevated content of $\mathrm{P}$ and $\mathrm{F}$. Their geochemical characters correspond to S-type granites.

(3) The genesis de the leucogranites corresponds to an independent magma batch and superimposed crystal fractionation process which distinguishes them from the inhomogeneous granitoids and the porphyritic granites. Likewise, this is shown by the field and petrographic data and the lack of geochemical affinity relationships with the remaining granites.

(4) All the granite units show subparallel REE patterns. There is a decrease in $\Sigma R E E$ and an increase in the negative $\mathrm{Eu}$ anomaly from the inhomogeneous granitoids to leucogranites. This is due to fractionation of the accessory minerals and/or the mobilisation of the REE to late post-magmatic fluids.

(5) The ages obtained from the whole-rock $\mathrm{Rb}-\mathrm{Sr}$ isochron indicate an early intrusion of the inhomogeneous granitoids $(319 \pm 10 \mathrm{Ma})$ followed in time by the porphyritic granites $(279 \pm 9 \mathrm{Ma})$, which is consistent with the observed field relationships. The ages obtained allow the Jálama batholith to be associated with the late-post-kinematic granites according to the last phase of ductile deformation, $\mathrm{D}_{3}$. The initial ${ }^{87} \mathrm{Sr} /{ }^{86} \mathrm{Sr}$ ratios suggest that the granites resulted from partial melting of pre-existing crustal material.

(6) The leucogranites present relatively large variations in Sn and W. The low content of these elements in some of the leucogranites is certainly due to the segregation from the magma of an aqueous melt enriched in $\mathrm{Sn}-\mathrm{W}$. As a consequence of this, it would have been impoverished of these elements in the last stages of magmatic consolidation. $\mathrm{Sn}$ and $\mathrm{W}$ concentrates in the final aqueous phase would give rise to mineralisation of these elements.

(7) From field observations of mineral occurrences and old workings of $\mathrm{Sn}$ in the Jálama batholith, mainly in the form of cassiterite, it can be shown that this mineralisation is associated with the leucogranites and the subfacies at the margin of the porphyritic granites. On the other hand, the internal porphyritic granites and the inhomogeneous granitoids do not exhibit mineralisation. Using trace elements as geochemical indicators of the $\mathrm{Sn}$ mineralisation potential, it can be shown that the granitic facies of the Jálama batholith with mineralising potential correspond exactly to those which exhibit mineralisation in the field. The criteria established to distinguish granitoids with mineralisation potential from barren ones have been effective. Likewise, we believe that this conclusion is not only valid for the Jálama batholith, but probably also in general, for the CIZ.

\section{Acknowledgements}

The authors are gratefully indebted to J. Reyes for permitting the use of analytical data of $\mathrm{Rb}-\mathrm{Sr}$ from the Jálama batholith; M. Regueiro, and L.G. Menéndez for their helpful suggestions. An anonymous referee provided constructive criticism that considerably helped to improve the manuscript. Financial support for this work was provided by the Geological Survey of Spain (IGME).

\section{Appendix A. Supplementary materials}

Supplementary data associated with this article can be found in the online version at doi:10.1016/j.chemer. 2006.11.001

\section{References}

Ayres, M., Harris, N., 1997. REE fractionation and Ndisotope disequilibrium during crustal anatexis: constraints from Himalayan leucogranites. Chem. Geol. 139, 249-269.

Bea, F., 1985. Los granitoides hercínicos de la mitad occidental del batolith de Àvila (sector de Gredos). Aproximación mediante el concepto de superficies. Rev. Real Acad. Cien. Ex. Fis. Nat. De Madrid 79, 549-572.

Bea, F., Sánchez, J.G., Serrano Pinto, M., 1987. Una compilación geoquímica (elementos mayores) de los granitoides del Macizo Hespérico. In: Bea, F., et al. (Eds.), Geología de los Granitoides del Macizo Hespérico. Rueda, Madrid, pp. 87-194. 
Bea, F., Fershtater, G., Corretge, L.G., 1992. The geochemistry of $\mathrm{P}$ in granitic rocks and the effect of aluminium. Lithos 29, 43-56.

Bea, F., Pereira, M.D., Corretgé, L.G., Fershtater, G.B., 1994. Differentiation of strongly peraluminous, perphosphorus granites: the Pedrobernardo pluton, central Spain. Geochim. Cosmochim. Acta 58, 2609-2627.

Bea, F., Montero, P., Zinger, T., 2003. The nature, origin and thermal influence of the granite source layer of Central Iberia. J. Geol. 111, 579-595.

Beus, A.A., Gregorian, S.V., 1975. In: Geochemical Exploration Methods for Mineral Deposits. Applied Pub. Ltd., Wilmette, IL, pp. 53-71.

Broska, I., Williams, C.T., Uher, P., Konecnỳ, P., Leichmann, J., 2004. The geochemistry of phosphorus in different granite suites of the Western Carpathians, Slovakia: the role of apatite and P-bearing feldspar. Chem. Geol. 205, $1-15$.

Candela, P., 1995. Do some miarolitic granites preserve evidence of magmatic volatile phase permeability? Econ. Geol. 90, 2310-2316.

Capdevilla, R., Corretgé, L.G., Floor, P., 1973. Les granitoïdes varisques de la Meseta Ibérique. Bull. Soc. Géol. France 15, 209-228.

Castro, A., Patiño Douce, A.E., Corretgé, L.G., et al., 1999. Origin of peraluminous granites and granodiorites, Iberian massif, Spain: an experimental test of granite petrogenesis. Contrib. Mineral. Petrol. 135, 255-276.

Chappell, B.W., 1999. Aluminium saturation in I- and S-type granites and the characterisation of fractionated haplogranites. Lithos 46, 535-551.

Chappell, B.W., White, A.J.R., 1974. Two contrasting granite types. Pacific Geol. 8, 173-174.

Clemens, J.D., 2003. S-type granitic magmas-petrogenetic issues, models and evidence. Earth-Sci. Rev. 61, 1-18.

Corretgé, L.G., 1983. Las rocas graníticas y granitóides del Macizo Hespérico. In: Libro Jubilar, J.M. Ríos, Geología de España, I, IGME, pp. 569-592.

Corretgé, L.G., Bea, F., Suárez, O., 1985. Las características geoquímicas del batolith de Cabeza de Araya (Cáceres, España): implicaciones petrogenéticas. Trab. Geol. Univ. Oviedo 15, 219-238.

Dall Agnol, R., Schuckmann, W., Basei, M.A.S., Scheller, T., 1984. Novos dados geocronológicos e estudo de elementos traços de maciços graníticos anorogênicos da Amazônia Oriental, Estado do Pará (Brasil). Simp. Geol. Amaz., 2, Manaus, 1984. Anais, Manaus, SBG, Núcleo Norte, pp. 59-74.

Dall Agnol, R., Lafon, J.M., Macambira, M.J.B., 1994. Proterozoic anorogenic magmatism in the Central Amazonian Province, Amazonian Cratón: geochronological, petrological and geochemical aspects. Mineral. Petrol. 50, $113-138$.

Debon, F., Le Fort, P., 1988. A cationic classification of common plutonic rocks and their magmatic associations: principles, method, applications. Bull. Minér. 111, 493-510.

Dias, G., Leterrier, A., Mendes, A., Simoes, P.P., Bertrand, J.M., 1998. U-Pb zircon and monazite geochronology of post-collisional Hercynian granitoids from The Central Iberian Zone (Northern Portugal). Lithos 45, 349-369.
Díez Balda, M.A., Vegas, R., González Lodeiro, F., 1990. Structure of the Central-Iberian Zone. In: Dallmeyer, R.D., Martínez García, E. (Eds.), Pre-Mesozoic Geology of Iberia. Springer, Berlin, Heidelberg, pp. 172-188.

Díez Balda, M.A., Martínez Catalán, J.R., Ayarza Arribas, P., 1995. Syncollisional extensional collapse parallel to the orogenic trend in a domain of steep tectonics: the Salamanca Detachment Zone (Central Iberian Zone, Spain). J. Struct. Geol. 17, 163-182.

Dunbar, N., Campbell, A., Candela, P., 1996. Physical, chemical and mineralogical evidence for magmatic fluid migration within the Capitan Pluton, south-eastern New Mexico. Bull. Geol. Soc. Am. 108 (3), 318-333.

Ferreira, N., Iglesias, M., Noroña, F., Pereira, E., Ribeiro, A., Ribeiro, M.L., 1987. Granitóides da Zona Centro Ibérica e seu enquadramento geodinámico. In: Bea, F., Carnicero, A., Gonzalo, J.C., López Plaza, M., Rodríguez Alonso, M.D. (Eds.), Geología de los Granitoides y Rocas Asociadas del Macizo Hespérico. Rueda, Madrid, pp. $37-51$.

Flynn, R.T., Burnham, C., 1978. An experimental determination of rare earth partition coefficients between a chloride containing vapour phase and silicate melts. Geochim. Cosmochim. Acta 42, 685-701.

Förster, H.J., 2001. Synchsite-(Y)-synchysite-(Ce) solid solutions from Markersbach, Erzgebirge, Germany: REE and Th mobility during high-T alteration of highly fractionated aluminous A-type granites. Mineral. Petrol. 72, 259-280.

Friedrich, M.H., Cuney, M., 1987. Uranium geochemistry in peraluminous leucogranites. Uranium 3, 353-385.

Fúster, J.M., Villaseca, C., 1988. El complejo plutónico hercínico-tardihercínico del Sistema Central Español. In: Bea, F., Carnicero, A., Gonzalo, J.C., López Plaza, M., Rodríguez Alonso, M.D. (Eds.), Geología de los Granitoides y Rocas Asociadas del Macizo Hespérico. Rueda, Madrid, pp. 27-36.

García de Figuerola, L.C., Bascones Alvira, L., Martín Herrero, D., 1985a. Mapa Geológico de España E. 1:50.000, Hoja 572, Memoria explicative, IGME.

García de Figuerola, L.C., Rodríguez Alonso, M.D., Bascones Alvira, L., Martín Herrero, D., 1985b. Mapa Geológico de España E. 1:50.000, Hoja 573, Memoria explicative, IGME.

Green, T.H., Watson, E.B., 1982. Crystallization of apatite in natural magma under high-pressure, hydrous conditions, with particular reference to orogenic" rock series. Contrib. Mineral. Petrol. 79, 96-105.

Haapala, I., 1977. Petrography and geochemistry of the Eurajoki stock, a rapakivi-granite complex with Greisentype mineralisation in south-western Finland. Finland Geol. Surv. Bull. 286.

Herreros, V., 1998. Petrología y geoquímica de los granitoides del sector oriental de Grados (Sistema Central Español). Ph.D. Thesis, University Complutense de Madrid, Spain.

Irber, W., 1999. The lanthanide tetrad effect and its correlation with $\mathrm{K} / \mathrm{Rb}, \mathrm{Eu} / \mathrm{Eu}^{*}, \mathrm{Sr} / \mathrm{Eu}, \mathrm{Y} / \mathrm{Hf}$ of evolving peraluminous granite suites. Geochim. Cosmochim. Acta 63, 439-508.

La Roche, H., 1992. Un homologue cationique du triangle Q-A-P (quartz-feldspath alcalin-plagioclase), figure majeure de la pétrologie des roches plutoniques. C.R. Acad. Sci. Paris 315, 1687-1693. 
Lehmann, B., 1990. Metallogeny of Tin. Lecture Notes in Earth Sciences, vol. 32. Springer, Berlin, p. 211.

London, D., 1992. Phosphorus in S-type magmas: the $\mathrm{P}_{2} \mathrm{O}_{5}$ content of feldspars from peraluminous granites, pegmatites and rhyolites. Am. Mineral. 77, 126-145.

Manning, D.A.C., Henderson, P., 1984. The behaviour of tungsten in granite-melt vapour systems. Contrib. Mineral. Petrol. 86, 286-293.

Martín Herrero, D., García de Figuerola, L.C., Bascones Alvira, L., 1984. Mapa Geológico de España E. 1:50.000, Hoja 596, Mem. Explicativa, IGME.

Martínez Catalán, J.R., 1990. A non-cylindrical model for the north-west Iberian allochthonous terranes and their equivalents in the Hercynian belt of Western Europe. Tectonophysics 179, 253-272.

Matte, Ph., 1986. La chaîne varisque parmi les chaînes plaéozoiques péri atlantiques, modèle d'évolution et position des grands blocs continentaux au Permo-Carbonifère. Bull. Soc. Géol. France 2, 9-24.

Montel, J.M., Mouchel, R., Pichavant, M., 1988. High apatite solubility in peraluminous melts. Terra Cognita 8, 71 .

Neiva, A.M.R., 1984. Geochemistry of tin-bearing granitic rocks. Chem. Geol. 43, 241-256.

Neiva, A.M.R., Gomes, M.E.P., 2001. Diferentes tipos de granites e seus processos petrogenéticos: granites hercínicos portugueses. Mem. Acad. Cienc. de Lisboa XXXIX, 53-95.

Neiva, A.M.R., Silva, M.M.V.G., Gomes, M.E.P., Campos, T.F.C., 2002. Geochemistry of coexisting biotite and muscovite of Portuguese peraluminous granitic differentiation series. Chem. Erde 62, 197-215.

Olade, M.A., 1980. Geochemical characteristics of tin bearing and tin-barren granites, Northern Nigeria. Econ. Geol. 75, 71-82.

Pagel, M., 1981. Facteurs de distribution et de concentration de l'uranium et du thorium dans quelques granites de la chaise Hercynnienne d'Europe. Thèse Institute Nationales Polytechnic Lorraine, Nancy, 556pp.

Ramírez, J.A., Grundvig, S., 2000. Causes of geochemical diversity in peraluminous granitic plutons: the Jalama pluton, Central-Iberian Zone (Spain and Portugal). Lithos 50, 171-190.

Ramírez, J.A., Menéndez, L.G., 1999. A geochemical study of two peraluminous granites from south-central Iberia: the Nisa-Alburquerque and Jalama batholiths. Mineral. Mag. 63 (1), 85-104.

Ribeiro, A., Iglesias, M., Ribeiro, M.L., Pereira, E., 1983. Modèle géodyamique des Hercynides Ibériques. Comn. Serv. Geol. Portugal 69, 291-293.

Robles, R., Àlvarez-Nava, H., 1988. Los materiales precámbricos-cámbricos del Domo de las Hurdes: existencia de tres series sedimentarias separadas por discordancias, SO de Salamanca (Zona Centroibérica). II Congreso Geológico de España I, 185-189.

Saavedra, J., 1982. Geochemistry of barren granites and those mineralised with tin and tungsten in West Central Spain. In: Evans, A. (Ed.), Metallization Associated with Acid Magmatism. Wiley, New York, pp. 291-300.

Saavedra, J., Pellitero, A., 1973. Estudio geoquímico de rocas ígneas del norte de la provincia de Cáceres. Stud. Geol. VI, $49-63$.
Saavedra, J., Pellitero, A., 1975. Factores geoquímicos en la génesis de los yacimientos de $\mathrm{Sn}$ y $\mathrm{W}$ asociado a rocas plutónicas ácidas. Aplicación al granito de Jálama. Tecniterrae, pp. 8-15.

Saavedra, J., Pellitero, A., García, A., Madruga, F., 1977. Estudio del granito mineralizado del Jálama, SalamancaCáceres, España. Bol. Geol. Mineral. 88, 333-344.

Scaillet, B., Pichavant, M., Roux, J., 1995. Experimental crystallization of leucogranite magmas. J. Petrol. 36, 663-705.

Scheepers, R., 2000. Granites of the Saldania mobile belt, South Africa: radioelements and $\mathrm{P}$ as discriminators applied to metallogeny. J. Geochem. Explor. 68, 69-86.

Serrano Pinto, M., Casquet, C., Ibarrola, E., Corretgé, L.G., Portugal Ferreira, M., 1987. Sintese geocronologica dos granitoides do maciço hesperico. In: Bea, F., Carnicero, A., Gonzalo, J.C., López Plaza, M., Rodríguez Alonso, M.D. (Eds.), Geología de los Granitoides y Rocas Asociadas del Macizo Hespérico. Rueda, Madrid, pp. 69-86.

Steiger, R.H., Järger, E., 1977. Subcommission on Geochronology: convention on the use of decay constants in geoand cosmochronology. Earth Planet. Sci. Lett. 36, 359-362.

Stone, M., Exley, C.S., 1985. High heat production granites granites of southwest England and their associated mineralisation: a review. In: High Heat Production Granites, Hydrotermal Circulation and Ore Genesis, Institute of Mining and Metallurgy Conference, pp. 571-593.

Strong, D.F., 1985. A review and model for granite-related mineral deposits. In: Taylor, R.P., Strong, D.F. (Eds.), Recent Advances in the Geology of Granite-Related Mineral Deposits. Proceedings of Canadian Institute of Mining and Metallurgy Conference, Granite-Related Mineral Deposits, pp. 424-445.

Tauson, L.V., Kozlov, V.D., 1973. Distribution functions and ratios of trace element, concentrations as estimates of orebearing potential of granites, in Geochemical Exploration 1977. Institute of Mining Metallurgy, London, pp. 37-44.

Taylor, R.P., Strong, D.F., Fryer, B.J., 1981. Volatile control of contrasting trace element distributions in peralkaline granitic and volcanic rocks. Contrib. Mineral. Petrol. 77, 267-271.

Tischendorf, G., 1977. Geochemical and petrographic characteristics of silicic magmatic rocks associated with rare element mineralisation. In: Stemprok, M., Burnol, L., Tischendorf, G. (Eds.), Symposium, Metallization Associated with Acid Magmatism (MAWAM): Prague Geological Survey, vol. 2, pp. 41-96.

Villaseca, C., 1985. Los granitos de la Sierra de Guadarrama. Rev. R. Acad. Cienc. Físicas, Exactas y Naturales 79, 573-587.

Villaseca, C., Herreros, V., 2000. A sustained felsic magmatic system: the Hercynian granitic batholith of the Spanish Central System. Trans. R. Soc. Edinburgh: Earth Sci. 91, 207-219.

Villaseca, C., Eugercios, L., Snelling, N.J., Huertas, M.J., Castellón, T., 1995. Nuevos datos geocronológicos ( $\mathrm{Rb}-\mathrm{Sr}$, $\mathrm{K}-\mathrm{Ar}$ ) de granitoides hercínicos de la Sierra de Guadarrama. Rev. Sociedad Geol. España 8, 129-140.

Villaseca, C., Barbero, L., Rogers, G., 1998. Crustal origin of Hercynian peraluminous granitic batholiths of Central Spain: petrological, geochemical and isotopic $(\mathrm{Sm}, \mathrm{Nd})$ constraints. Lithos $43,55-79$. 
Watson, E.B., 1985. Henry's law behaviour in simple systems and in magmas: criteria for discerning concentrationdependent partition coefficients in nature. Geochim. Cosmochim. Acta 49, 917-923.

Watt, G.R., Harley, S.L., 1993. Accessory phase controls on the geochemistry of crustal melts and restites pro- duced during water-undersaturated partial melting. Contrib.Mineral. Petrol. 114, 550-566.

White, A.J.R., Chappell, B.W., 1988. Some supracrustal (S-type) granites of the Lach Lan Fold Belt. Trans. R. Soc. Edinburgh 79, 169-181. 